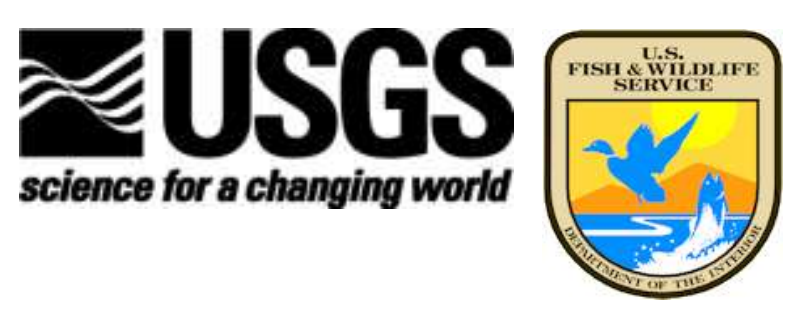

\title{
A Tool for Prioritizing Management Units at Morris Wetland Management District
}

U.S. Department of the Interior U.S. Geological Survey 



\title{
A Tool for Prioritizing Management Units at Morris Wetland Management District
}

\author{
By \\ Jason Rohweder \\ United States Geological Survey \\ Upper Midwest Environmental Sciences Center \\ 2630 Fanta Reed Road \\ La Crosse, WI 54603 \\ jrohweder@usgs.gov \\ and \\ Sara Vacek \\ United States Fish and Wildlife Service \\ Morris Wetland Management District \\ $43875230^{\text {th }}$ St. \\ Morris, MN 56267 \\ SaraVacek@fws.gov \\ and \\ Wayne E. Thogmartin \\ United States Geological Survey \\ Upper Midwest Environmental Sciences Center \\ 2630 Fanta Reed Road \\ La Crosse, WI 54603 \\ wthogmartin@usgs.gov
}

\author{
Prepared for \\ United States Fish and Wildlife Service \\ July 2011
}

Mention of trade names or commercial products does not constitute endorsement or recommendation for use by the U.S. Department of Interior, U.S. Geological Survey. 


\section{Contents}

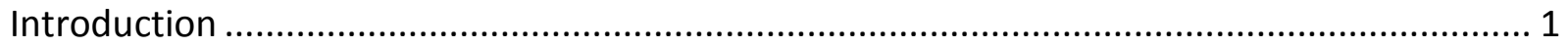

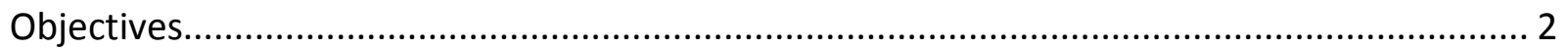

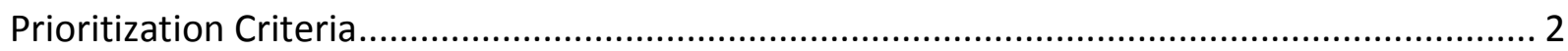

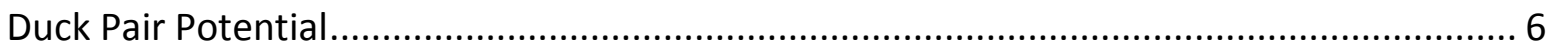

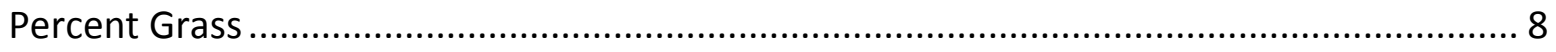

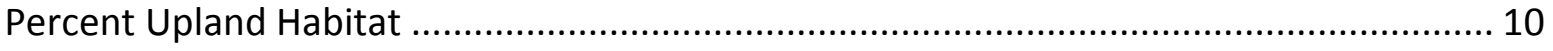

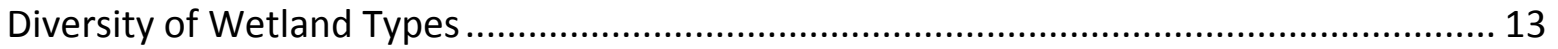

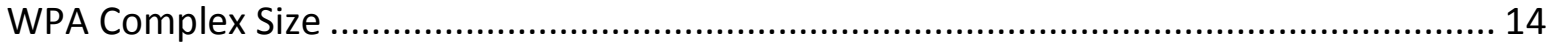

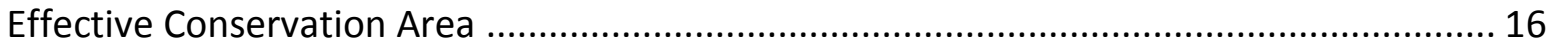

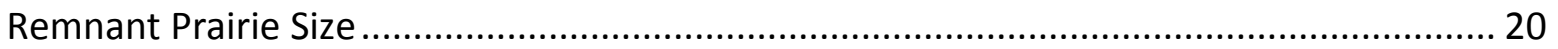

Proximity to Human Development ......................................................................... 22

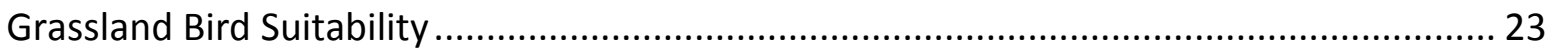

Percentage of Wetlands Non-drained (Natural) ............................................................... 26

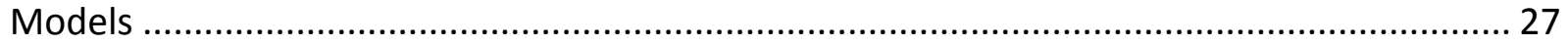

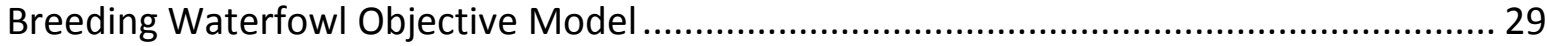

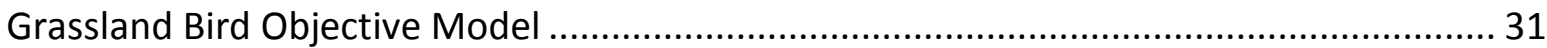

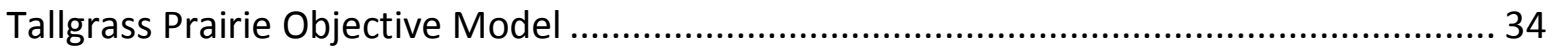

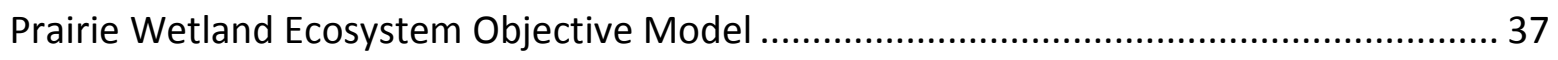

Threatened and Endangered Species Objective Model ................................................ 40

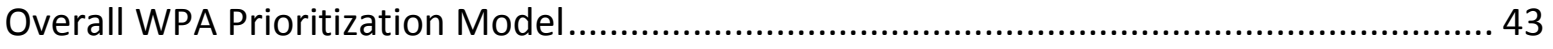

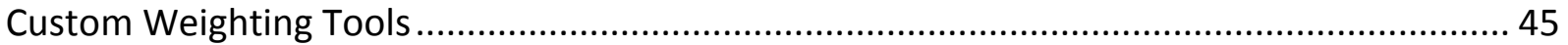

Overall WPA Prioritization Model Custom Weighting Tool ............................................... 45

Objective Model Custom Weighting Tool ..................................................................... 47

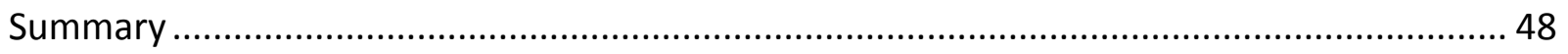

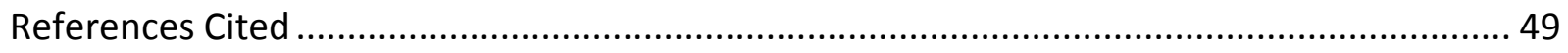

Appendix 1. List of attendees at original Morris Wetland Management District prioritization

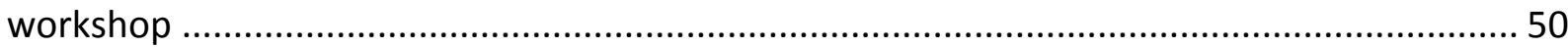

Appendix 2. Full list of WPAs, ranked in order from most important to least important relative to the Overall WPA Prioritization Model. 


\section{List of Figures}

Figure 1. Location of Morris WMD.

Figure 2. Modified breeding pair accessibility map. WPAs with the top 10 mean scores for the duck pair potential criterion are highlighted.

Figure 3. Modified percent grass map. WPAs with the top 10 mean scores for the percent grass criterion are highlighted.

Figure 4. Percent upland habitat map. WPAs with the top 10 scores for the percent upland

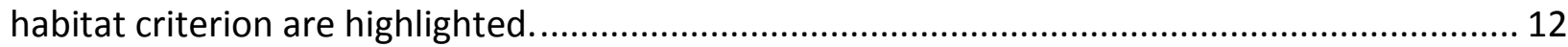

Figure 5. Wetland type diversity map......................................................................... 14

Figure 6. Waterfowl Production Area (or WPA complex) size map. The top 10 largest WPAs or

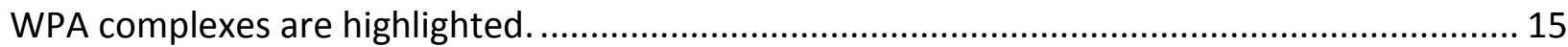

Figure 7. Close-up view of how effective areas were delineated........................................... 18 Figure 8. Effective conservation area map. WPAs with the top 10 largest effective conservation areas are highlighted.

Figure 9. Remnant prairie size map. WPAs with the top ten amounts of remnant prairie are highlighted.

Figure 10. Proximity to human development map. A low value indicates a closer proximity to human development.

Figure 11. Modified grassland bird suitability map. WPAs with the top 10 mean scores for the grassland bird suitability criterion are highlighted.

Figure 12. Percent of wetland area on each WPA that is non-drained................................. 27

Figure 13. Diagram depicting how weighted overlay functions ........................................... 28

Figure 14. Breeding waterfowl model output map. WPAs with the top 10 scores for this model are highlighted. 30

Figure 15. Grassland bird model map. WPAs with the top 10 scores for this model are highlighted.

Figure 16. Tallgrass prairie model output map. WPAs with the top 10 scores for this model are highlighted. 36

Figure 17. Prairie wetland ecosystem model output map. WPAs with the top 10 scores for this model are highlighted.

Figure 18. Threatened and endangered species map. WPAs with the top 10 scores for this model are highlighted.

Figure 19. Overall prioritization model results map. WPAs with the top 10 scores for this model are highlighted.

Figure 20. Dialog window for the Overall WPA Prioritization Model Custom Weighting Tool ... 46 Figure 21. Dialog window for the Objective Model Custom Weighting Tool 


\section{List of Tables}

Table 1. Morris WMD priority resources of concern and priority habitats as identified in the habitat management plan.

Table 2. Final list of criteria and related data sets used to prioritize waterfowl production areas (WPAs) in Morris Wetland Management District. Note: scale indicates whether the data set describes only the WPA or also reflects information about the surrounding landscape.

Table 3. Top ranked WPAs in terms of the duck pair potential criterion. The mean scores listed are before normalization (scale is 0 to 75 ).

Table 4. Top ranked WPAs in terms of percent grass criterion. Mean scores listed are before normalization (scale is 0 to 68 ).

Table 5. Upland and wetland habitat classes in the Morris WMD Habitat Layer, showing the breakdown between upland and wetland classes. Wetland types listed follow Ciricular 39 (Shaw and Fredine 1956), with classification codes per Cowardin and others (1979) in parentheses.

Table 6. Top ranked WPAs in terms of the percent upland habitat criterion. Percent upland values listed are before normalization (scale is 0 to $98.72 \%$ ).

Table 7. Wetland classes from the Morris WMD Habitat Layer and corresponding wetland types used for this criterion.

Table 8. Top ranked WPAs in terms of the WPA complex size criterion. WPA complex acres are before normalization (scale is 6.7 to 2003.9 acres).

Table 9. Number of WPAs selected as "adjacent" to other conservation lands with increasing buffer distances.

Table 10. Top ranked WPAs in terms of the effective conservation area criterion. Effective acres listed are before normalization (scale is 6.7 to $49,565.4$ acres).

Table 11. Top ranked WPAs in terms of native prairie size criterion. Values for acres of native prairie are before normalization (scale is 0.00 to 634.99 acres).....

Table 12. Top ranked WPAs in terms of the grassland bird suitability criterion. The mean score listed is before normalization (scale is 0 to 52 grassland bird nesting pairs/40 acres). ......................................26

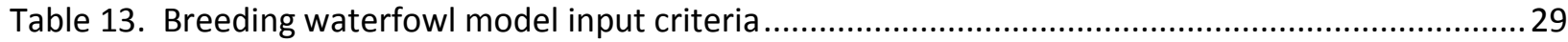

Table 14. Top ranked WPAs in terms of mean breeding waterfowl score .............................................. 31

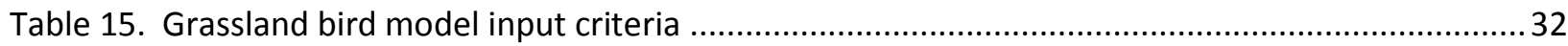

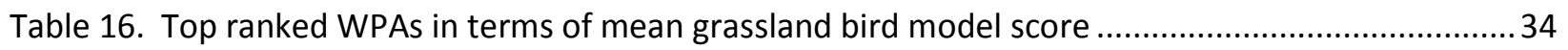

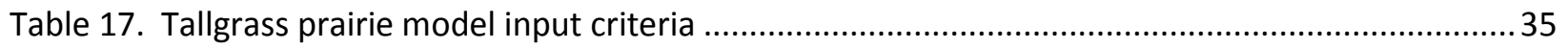

Table 18. Top ranked WPAs in terms of mean tallgrass prairie model score ..........................................37

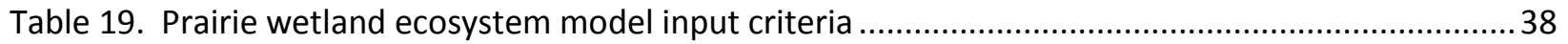

Table 20. Top ranked WPAs in terms of mean prairie wetland ecosystem model score .........................40

Table 21. Number of occurrences for each threatened and endangered species $(E=$ endangered, $T=$

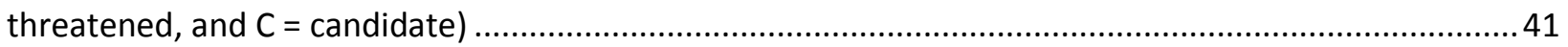

Table 22. Top ranked WPAs in terms of mean threatened and endangered species score.....................43

Table 23. Overall prioritization model individual objective model weighting breakdown........................ 43

Table 24. Top ranked WPAs in terms of mean overall prioritization model score. Individual objective model scores are provided for comparison (darker red cells indicate the relative ranking of the WPA for

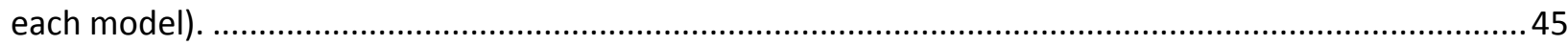

Table 25. Comparison of even and customized weights for Overall WPA Prioritization Model ...............47

Table 26. Top ranked WPAs under two different model weight scenarios .......................................... 47 


\section{Introduction}

Where are the most important places to direct conservation effort? Such a simple question is not answered simply. There are a myriad of priorities, constraints, and capacities, both scientific and socio-economic, which in combination guide the allocation of management effort. An honest accounting of these priorities, constraints, and capacities is essential for efficient, effective action.

Morris Wetland Management District (WMD), a land management office of the United States Fish and Wildlife Service (USFWS), was established in 1964 to preserve and protect habitat critical to waterfowl and other prairie wildlife. Morris WMD manages 245 separate parcels of federally owned land called Waterfowl Production Areas (WPA) within an eight county district (Big Stone, Lac Qui Parle, Pope, Stevens, Swift, Traverse, Yellow Medicine and Chippewa). Together, the 245 WPAs encompass over 50,000 acres of land dedicated to wildlife and wildlife dependent public recreation. Morris WMD also oversees over 26,000 acres of privately owned wetlands and grasslands that, while remaining privately owned, are protected by permanent conservation easements.

Morris WMD will soon complete its Habitat Management Plan (HMP), which clearly identifies priority resources for the district (Table 1). The HMP guides management by describing habitat objectives and management strategies that will best support those priority resources.

However, while Morris WMD is charged with managing a myriad of natural resources over a large geographic area, it does not possess sufficient resources to manage every unit to its full potential. The issue of where to manage given limited resources is the biggest concern Morris WMD faces in implementing the HMP.

This document describes a decision support tool that will help Morris WMD make thoughtful and strategic choices about where to spend its limited management resources. It incorporates landscape and management unit features to identify which WPAs have the greatest biological potential with respect to priority resources and habitats. The district can use this information to prioritize and target management, which will help with development of annual habitat plans. This tool could also be used to help the staff prioritize private lands efforts. Additionally, we provide the database structure in the hope other refuges and districts will find this tool useful in the development of their own HMPs. 
Table 1. Morris WMD priority resources of concern and priority habitats as identified in the habitat management plan.

\begin{tabular}{|c|c|c|c|c|c|}
\hline \multirow[b]{3}{*}{$\begin{array}{c}\text { Priority Resource of } \\
\text { Concern }\end{array}$} & \multicolumn{5}{|c|}{ Priority Habitat } \\
\hline & \multicolumn{2}{|c|}{ Grassland } & \multicolumn{3}{|c|}{ Wetland } \\
\hline & Remnant & Planted & $\begin{array}{c}\text { Temporary/ } \\
\text { Seasonal }\end{array}$ & $\begin{array}{c}\text { Semi- } \\
\text { permanent }\end{array}$ & $\begin{array}{l}\text { Permanent/ } \\
\text { Shallow Lake }\end{array}$ \\
\hline Mallard & $x$ & $x$ & $x$ & $\mathrm{X}$ & \\
\hline Blue-winged Teal & $x$ & $x$ & $\mathrm{x}$ & $\mathrm{X}$ & \\
\hline Redhead & & & & $x$ & $X$ \\
\hline Western Meadowlark & $x$ & $x$ & & & \\
\hline Greater Prairie Chicken & $x$ & $x$ & & & \\
\hline Marbled Godwit & $x$ & & $x$ & $x$ & \\
\hline Sedge Wren & $x$ & $x$ & $x$ & & \\
\hline Grasshopper Sparrow & $x$ & $x$ & & & \\
\hline Northern Harrier & $x$ & $x$ & $x$ & $X$ & \\
\hline Upland Sandpiper & $x$ & $x$ & & & \\
\hline Willow Flycatcher & $x$ & $x$ & $x$ & & \\
\hline Dakota Skipper & $\mathrm{X}$ & & & & \\
\hline Powesheik Skipperling & $x$ & & & & \\
\hline Arogos Skipper & $\mathrm{X}$ & & & & \\
\hline Remnant Prairie & $x$ & & & & \\
\hline Natural Wetlands & & & $\mathrm{X}$ & $X$ & $x$ \\
\hline
\end{tabular}

A second phase of the tool, should the station choose to pursue it, will incorporate monetary costs and other constraints into the ranking process. This second phase may also look at identifying lands not currently managed by the USFWS but that would be valuable easements or possible fee acquisitions. This report and the analyses described here cover only Phase 1.

\section{Objectives}

Objectives for the district include managing wetland and grassland habitats to maximize waterfowl production, maintain suitable habitat for grassland birds, maintain remnant native prairies, manage for threatened and endangered species, and manage for prairie wetland ecosystem integrity. The priority resources of concern listed in Table 1 were chosen to reflect those objectives. Morris WMD is also concerned with other guilds of migratory birds, such as shorebirds and marshbirds, but the staff felt that their habitat needs would be met by meeting the habitat requirements listed above.

\section{Prioritization Criteria}

For several years, Morris WMD staff members discussed the need for finding a better way to make decisions about where in the district to use their limited management resources. Steve Delehanty, former Morris WMD Project Leader, developed a list of priority WPAs for the district 
based on landscapes with high potential for waterfowl production ( $>40$ pairs/sq mile) or grassland bird habitat ( $>20 \%$ grass in the landscape). While this was a useful starting point, district personnel recognized that there were many other variables that could influence which WPAs should be a priority for management attention.

Morris WMD decided to hold a structured decision making workshop to further develop the concept of priority management areas and to identify potential prioritization criteria. On December 8, 2009 the entire Morris WMD staff and several partners (see Appendix 1 for a list of attendees, their agency affiliation, and identified role) gathered to begin the effort that ultimately led to the management prioritization tool described in this document.

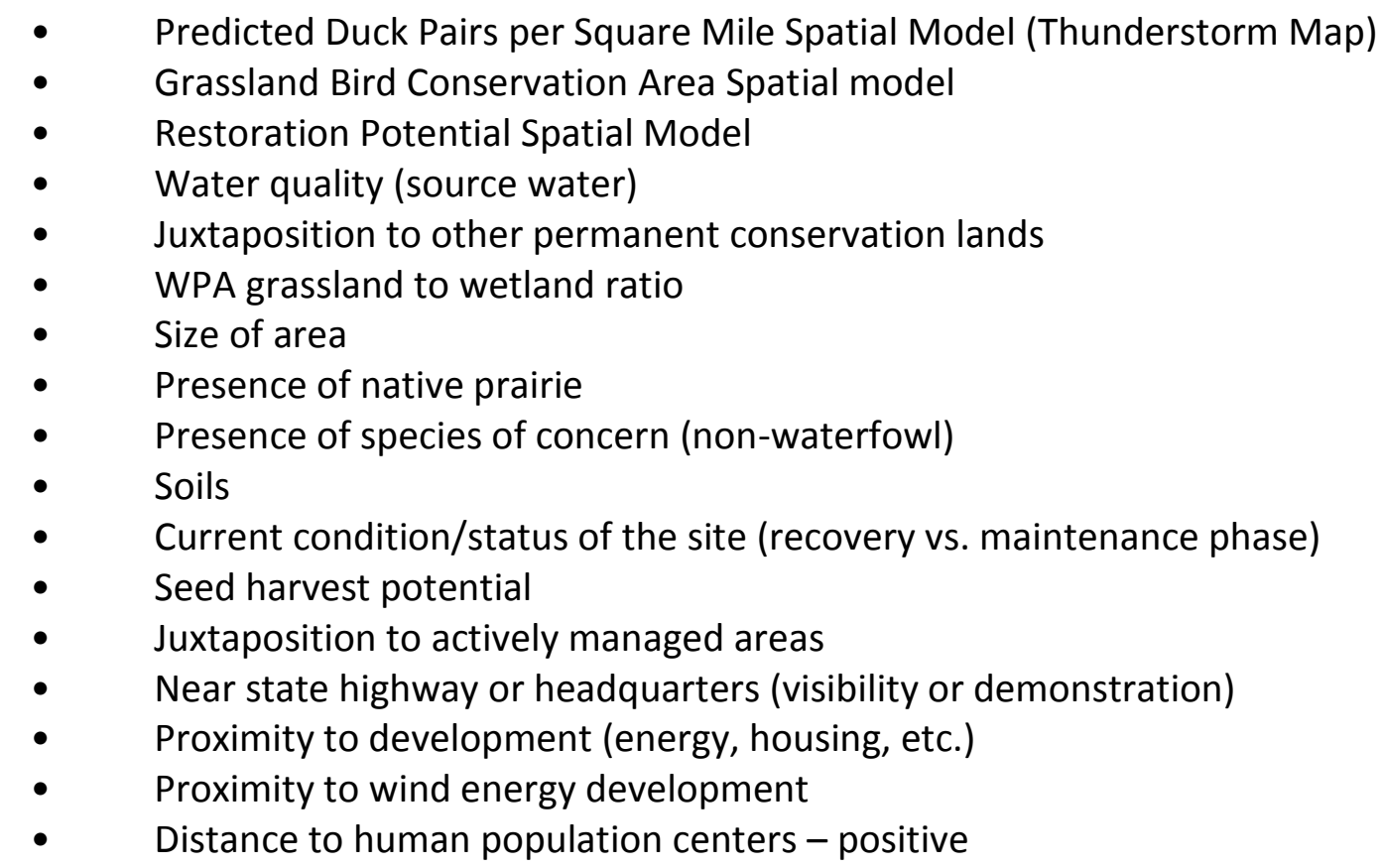

To build the prioritization models, we assembled spatial data to represent each of the criteria. Spatial data sets (in the form of GIS data layers) were assembled from several sources. Data layers were selected that were the most recent, accurate, had the greatest spatial and thematic resolution, and were available for the entire WMD. As a result, some of the criteria identified during the workshop were further refined or removed. We did not use previously-identified criteria when there was not a spatial data set available (e.g., water quality), when it was difficult to explain how features of the criteria related specifically to station objectives (e.g., soils), or when we determined that they were more accurately used as a non-biological constraint that would influence management decisions on an annual basis (e.g., seed harvest potential). The final criteria and associated data sets used in the models are listed in Table 2.

The boundary for Morris WMD accounts for an area exceeding 3.3 million acres $\left(>13,355 \mathrm{~km}^{2}\right)$. Data layer manipulation and analysis used ArcGIS 9.3.1 (Environmental Systems Research Institute, Redlands, California). This software allows for organized storage, manipulation, and publishing of the various relevant data layers used. 
Table 2. Final list of criteria and related data sets used to prioritize waterfowl production areas (WPAs) in Morris Wetland Management District. Note: scale indicates whether the data set describes only the WPA or also reflects information about the surrounding landscape.

\begin{tabular}{|c|c|c|c|c|}
\hline Criteria & Tool/Data Set & Source & Scale & $\begin{array}{l}\text { Unit of } \\
\text { Measure }\end{array}$ \\
\hline Duck pair potential & $\begin{array}{l}\text { Breeding Pair } \\
\text { Accessibility } \\
\text { Maps } \\
\text { (Thunderstorm } \\
\text { maps) }\end{array}$ & $\begin{array}{l}\text { USFWS, } \\
\text { Habitat and } \\
\text { Population } \\
\text { Evaluation } \\
\text { Team (HAPET) }\end{array}$ & Landscape & Pairs/sq mile \\
\hline Percent grass & $\%$ Grass model & USFWS, HAPET & Landscape & Percent grass \\
\hline Percent upland habitat & $\begin{array}{l}\text { Morris habitat } \\
\text { layer }\end{array}$ & Morris WMD & WPA & $\begin{array}{l}\text { Percent } \\
\text { Upland }\end{array}$ \\
\hline Diversity of wetland types & $\begin{array}{l}\text { Morris habitat } \\
\text { layer }\end{array}$ & Morris WMD & WPA & $\begin{array}{l}\text { Number of } \\
\text { wetland types } \\
\text { present }\end{array}$ \\
\hline WPA complex size & $\begin{array}{l}\text { FWS interest } \\
\text { layer }\end{array}$ & Morris WMD & WPA & Acres \\
\hline Effective conservation area & $\begin{array}{l}\text { Conservation } \\
\text { estate layers }\end{array}$ & Morris WMD & WPA & Acres \\
\hline Remnant prairie size & $\begin{array}{l}\text { Morris habitat } \\
\text { layer }\end{array}$ & Morris WMD & WPA & Acres \\
\hline $\begin{array}{l}\text { Proximity to human } \\
\text { development }\end{array}$ & $\begin{array}{l}\text { City and town } \\
\text { layer }\end{array}$ & Morris WMD & Landscape & Miles \\
\hline Grassland bird suitability & $\begin{array}{l}\text { Grassland bird } \\
\text { models }\end{array}$ & USFWS, HAPET & Landscape & Pairs/40 ac \\
\hline $\begin{array}{l}\text { Threatened and } \\
\text { endangered species }\end{array}$ & $\begin{array}{l}\text { Natural Heritage } \\
\text { Database }\end{array}$ & $\begin{array}{l}\text { MN } \\
\text { Department of } \\
\text { Natural }\end{array}$ & Landscape & $\mathrm{Y} / \mathrm{N}$ \\
\hline $\begin{array}{l}\text { Percentage of wetlands } \\
\text { non-drained (natural) }\end{array}$ & $\begin{array}{l}\text { National } \\
\text { Wetland }\end{array}$ & USFWS, HAPET & WPA & $\begin{array}{l}\text { Percent non- } \\
\text { drained }\end{array}$ \\
\hline
\end{tabular}




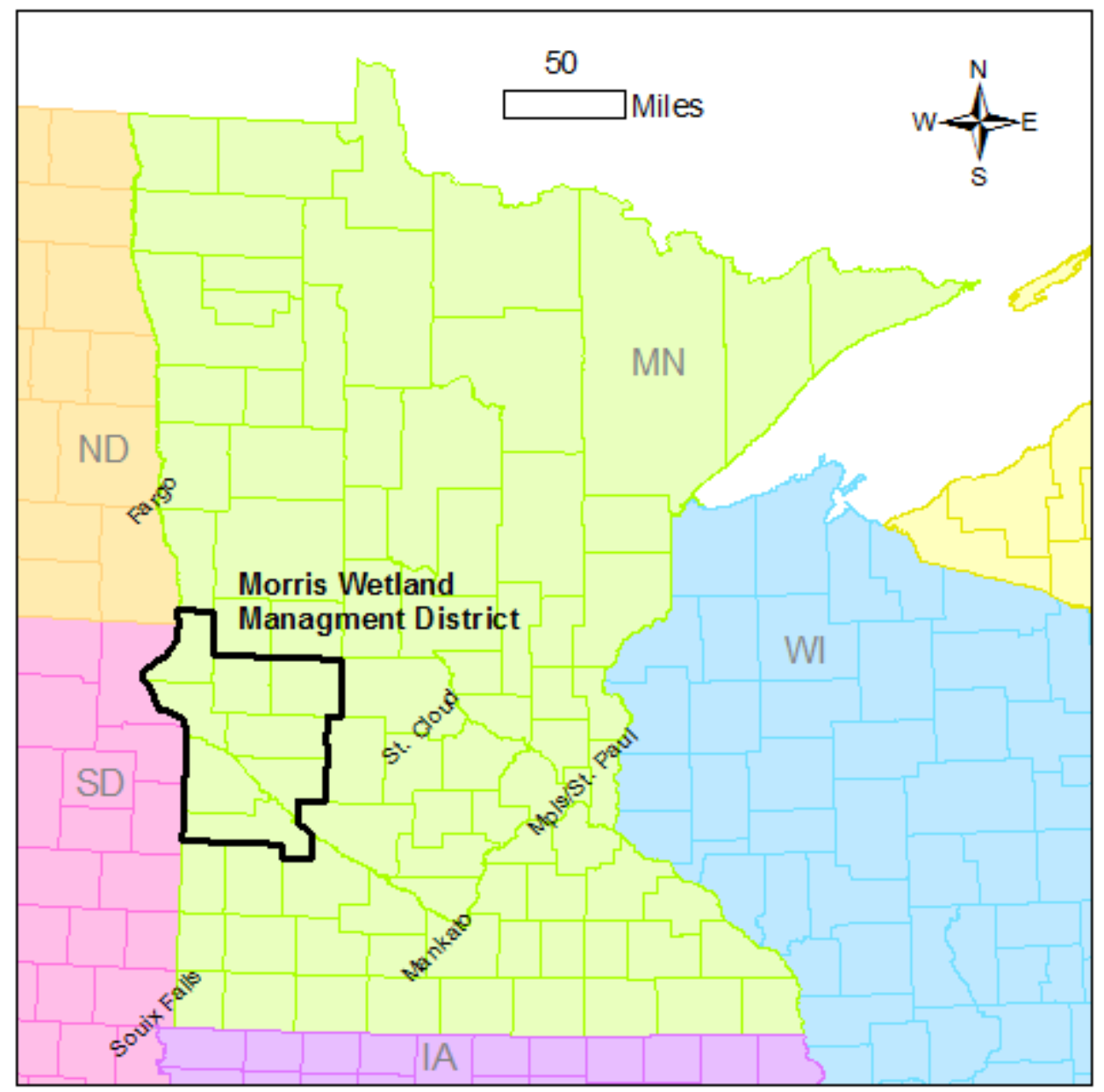

Figure 1. Location of Morris WMD.

Before developing the models, the values for each of the input data layers were reclassified from the initial dissimilar class descriptions (e.g., comparing proximity to human development to grassland bird suitability) into a consistent, normalized integer score ranging from 0 to 100 . Higher scores were given to an attribute if it was the preferred characteristic. Some of the reclassification involved simply reassigning values to unique classes, whereas some reclassification required grouping values into distinct ranges or bins based upon an equal interval classification method. Equal interval was selected because it emphasizes the amount of an attribute value relative to other values, for example, to show that a WPA is part of the group of WPAs that made up the top one-third of all by size.

In the following sections, each input spatial data layer is described briefly and a sample figure depicts the data graphically. The WPAs with the highest scores for a particular input variable are labeled in red. A "high" value denotes areas which are of higher quality or greater value to the district, whereas "low" values denote areas of lower quality or lesser value to the district. The relevance and importance of each criterion varies by the model in which it is used, so the 
justification and weights for the criteria are explained with the description of each model, beginning on p. 27.

\section{Duck Pair Potential}

We used breeding pair accessibility maps (i.e., thunderstorm maps) from the USFWS Habitat and Population Evaluation Team (HAPET) in Fergus Falls, MN, to describe the duck pair potential of a WPA. We used the third generation of models that were based on over 20 years of data (U.S. Fish and Wildlife Service, n.d.a).

Breeding pair accessibility maps are produced from long-term 4-square-mile survey data. They are commonly known as "Thunderstorm Maps" because of a perceived resemblance to a Doppler radar image of a thunderstorm. Thunderstorm maps display predictions of the number of upland nesting duck pairs (mallards, blue-winged teal, gadwall, northern pintail, and northern shoveler) that could potentially nest in the upland habitats of every 40 acre block of the Prairie Pothole Region (PPR) of Minnesota and lowa. These predictions are based on the known maximum travel distances of hens from wetlands to their nest sites, and regressions created from 4 square mile survey data predicting the number of duck pairs that utilize every individual wetland in the PPR during a "typical" breeding season (U.S. Fish and Wildlife Service, n.d.a).

The data were received as a raster data set with 40 acre cells. To make the data useable within the tool it first needed to be converted to a raster with 50 meter $\times 50$ meter cells. This was accomplished using the focalstatistics tool within ArcGIS' spatial analyst tool box. The tool first converted the input raster into a new raster with 50 meter $\times 50$ meter cells; each cell was then reattributed according to the average value of all 50 meter $x 50$ meter cells within a rectangle 400 meters $\times 400$ meters (roughly 40 acres). This has the effect of smoothing out the values over the landscape. The minimum and maximum values within this data layer were 0 and 75 duck pairs $/ \mathrm{mi}^{2}$, and those values were normalized between a minimum score of 0 and a maximum score of 100. The results of this analysis are displayed in Figure 2 and Table 3. 


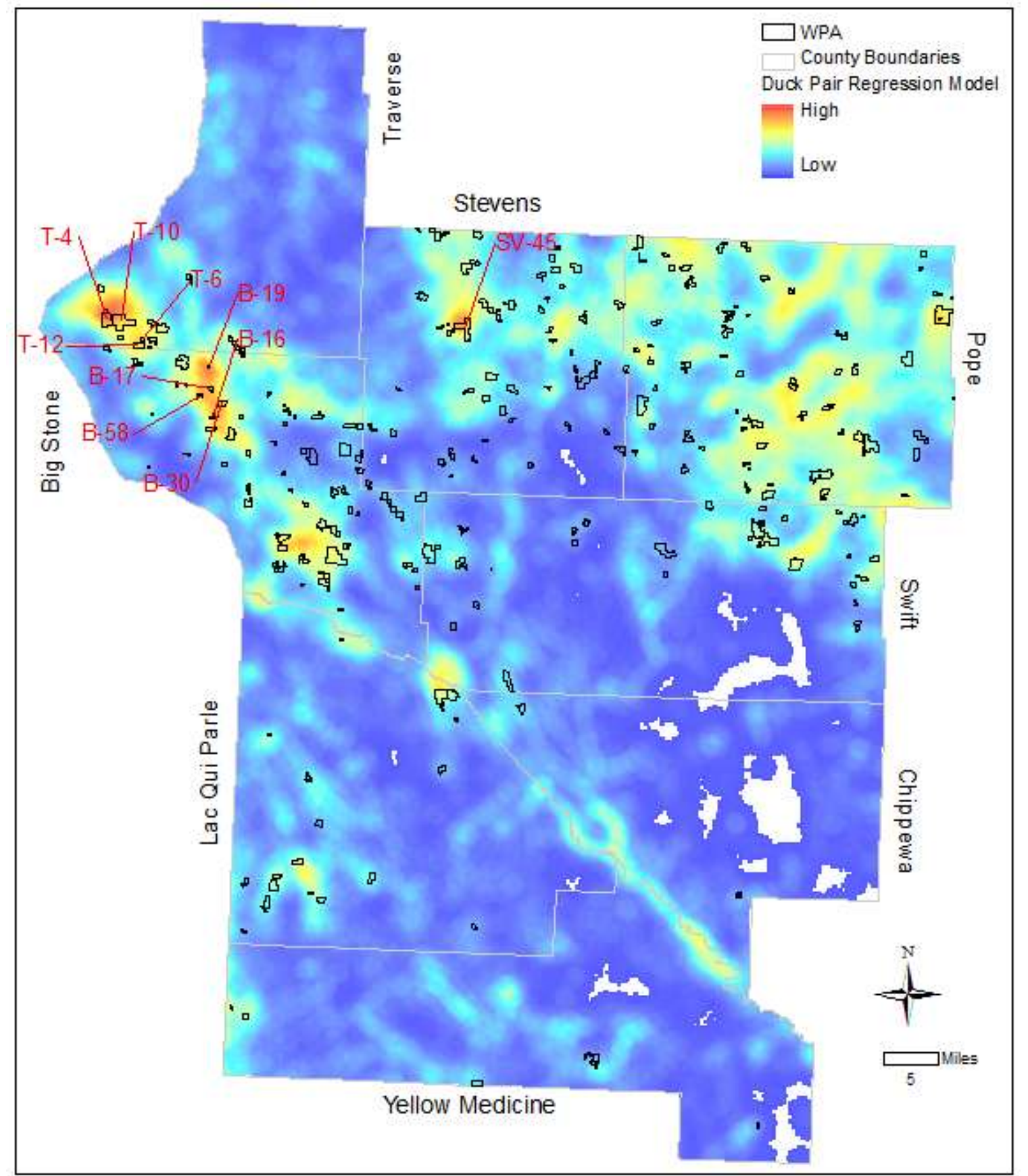

Figure 2. Modified breeding pair accessibility map. WPAs with the top 10 mean scores for the duck pair potential criterion are highlighted. 
Table 3. Top ranked WPAs in terms of the duck pair potential criterion. The mean scores listed are before normalization (scale is 0 to 75 ).

\begin{tabular}{|l|l|l|c|c|}
\hline Rank & WPA ID & WPA Name & WPA Size (acres) & Mean Duck Pair Score \\
\hline 1 & T-4 & $\begin{array}{l}\text { Mosquito } \\
\text { Ranch }\end{array}$ & 753.0 & 67.5 \\
\hline 2 & B-19 & Curran & 25.9 & 67.1 \\
\hline 3 & T-10 & Robin Hood & 1250.9 & 58.6 \\
\hline 4 & B-17 & O'Connell & 62.2 & 58.4 \\
\hline 5 & B-58 & Lane & 91.9 & 58.1 \\
\hline 6 & B-16 & Beck & 113.0 & 56.6 \\
\hline 7 & SV-45 & Pepperton & 918.0 & 56.2 \\
\hline 8 & T-6 & Jenk & 65.6 & 56.1 \\
\hline 9 & B-30 & Seidl & 224.0 & 55.2 \\
\hline 10 & T-12 & Diekmann & 319.5 & 53.6 \\
\hline
\end{tabular}

\section{Percent Grass}

The percent grass in a WPA's landscape was identified using another spatial data set developed and provided by HAPET. Landsat Thematic Mapper Satellite Imagery (30-meter resolution) was used to identify upland land cover using a combination of classification techniques. Image classification techniques were applied along with ground-truth information to classify image signatures into 15 classes of aquatic and upland habitat types. Percent grassland information in these maps was generated with GIS modeling techniques and represents the percent of landscapes comprised of grassland within all potential home ranges of nesting mallard hens. A moving window technique was used to calculate the amount of grassland habitat within 2 miles of each cell. These maps were produced as part of a joint project between the HAPET and the Ducks Unlimited Great Plains Regional Office, Bismarck, North Dakota (U.S. Fish and Wildlife Service, n.d.b).

The data were received as a raster data set with 40 acre cells. To make the data useable within the tool it first needed to be converted to a raster with 50 meter $\times 50$ meter cells. This was again accomplished using the focalstatistics tool and each cell was again reattributed according to the average value of all 50 meter $\times 50$ meter cells within a rectangle 400 meters $\times 400$ meters. The minimum and maximum values (percent grass) within this data layer were 0 and $68 \%$, and these values were normalized between a minimum score of 0 and a maximum score of 100. Figure 3 and Table 4 show results of the modified Percent Grass data set. 


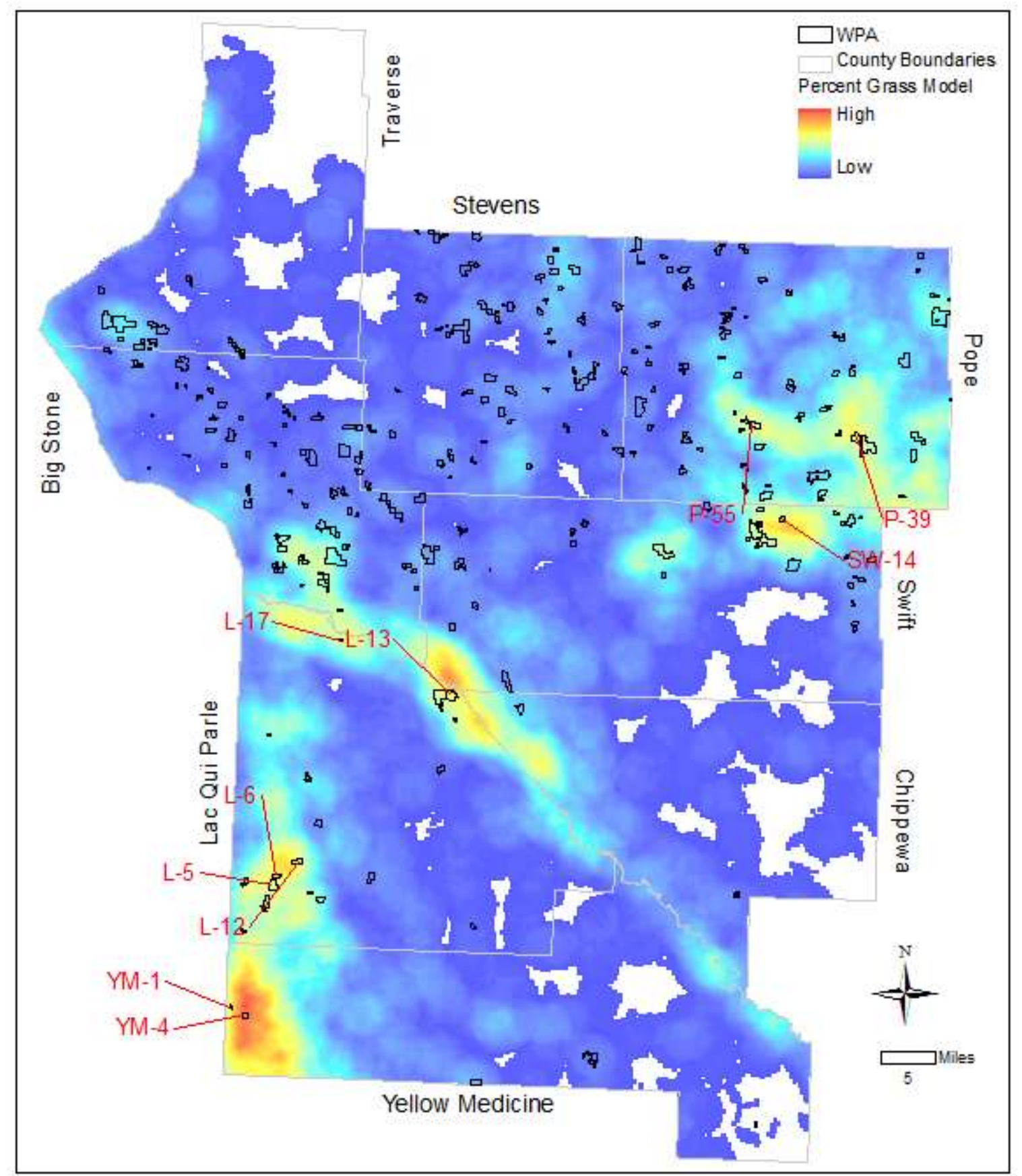

Figure 3. Modified percent grass map. WPAs with the top 10 mean scores for the percent grass criterion are highlighted. 
Table 4. Top ranked WPAs in terms of percent grass criterion. Mean scores listed are before normalization (scale is 0 to 68 ).

\begin{tabular}{|l|l|l|c|c|}
\hline Rank & WPA ID & WPA Name & WPA Size (acres) & Mean Percent Grass \\
\hline 1 & YM-4 & Dakota & 150.8 & 63.4 \\
\hline 2 & L-13 & Hegland & 463.3 & 46.0 \\
\hline 3 & L-6 & Bolson Slough & 178.7 & 44.9 \\
\hline 4 & YM-1 & Kontz & 26.5 & 43.5 \\
\hline 5 & SW-14 & Swift Falls & 121.4 & 42.4 \\
\hline 6 & L-12 & Goodman & 235.8 & 41.5 \\
\hline 7 & P-39 & Overby & 313.8 & 41.1 \\
\hline 8 & L-5 & Farrell & 400.6 & 39.5 \\
\hline 9 & P-55 & Blue Mounds & 392.8 & 38.0 \\
\hline 10 & L-17 & Plover & 32.4 & 37.6 \\
\hline
\end{tabular}

\section{Percent Upland Habitat}

The percent upland habitat was calculated for each WPA using the Morris WMD Habitat Layer. The habitat layer was digitized by Morris WMD staff from 1998 to the present. Multiple resources were used in the digitizing process, including station files, Resource Inventory and Protection maps (hand-drawn maps), aerial photography, and National Wetland Inventory data. Approximately $50 \%$ of WPAs have been ground-truthed, which includes any new acquisitions since 1992.

Waterfowl managers often refer to percent upland habitat as the upland to wetland ratio. Each habitat feature attribute was first categorized into an "upland" or "wetland" class type (Table 5). The percent of each WPA that was classified as upland was then calculated. The minimum and maximum values within this data layer were 0 and $98.72 \%$, and these values were normalized between a minimum score of 0 and a maximum score of 100 . Results for this data layer are shown in Figure 4 and Table 6. 
Table 5. Upland and wetland habitat classes in the Morris WMD Habitat Layer, showing the breakdown between upland and wetland classes. Wetland types listed follow Ciricular 39 (Shaw and Fredine 1956), with classification codes per Cowardin and others (1979) in parentheses.

\begin{tabular}{|c|c|}
\hline \multirow{13}{*}{ 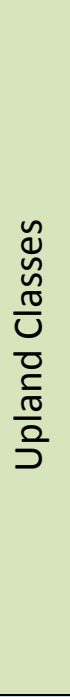 } & Brush \\
\hline & Cropland \\
\hline & Food Plot \\
\hline & Grass Dense Nesting Cover \\
\hline & Grass Introduced \\
\hline & Grass Native Prairie \\
\hline & Grass Seeded Cool \\
\hline & Grass Seeded Warm \\
\hline & Plantation Mixed \\
\hline & Plantation Shrub \\
\hline & Plantation Tree \\
\hline & Sparse Vegetation \\
\hline & Trees \\
\hline \multirow{10}{*}{ 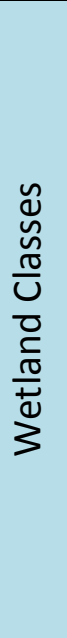 } & Lake \\
\hline & River \\
\hline & Stock Pond (PUBF) \\
\hline & Wetland Type 1 (PEMA - Palustrine, Emergent, Temporary Flooded) \\
\hline & Wetland Type 2 (PEMB - Palustrine, Emergent, Saturated) \\
\hline & Wetland Type 3 (PEMC - Palustrine, Emergent, Seasonally Flooded) \\
\hline & $\begin{array}{l}\text { Wetland Type } 4 \text { (PEMF - Palustrine, Emergent, Semipermanently } \\
\text { Flooded, PUBF - Palustrine, Unconsolidated Bottom, Semipermanently } \\
\text { Flooded) }\end{array}$ \\
\hline & Wetland Type 5 (PEMH - Palustrine, Emergent, Permanently Flooded) \\
\hline & Wetland Type 6 (PSSA - Palustrine, Scrub-Shrub, Temporary Flooded) \\
\hline & Wetland Type 7 (PFOB - Palustrine, Forested, Saturated) \\
\hline
\end{tabular}




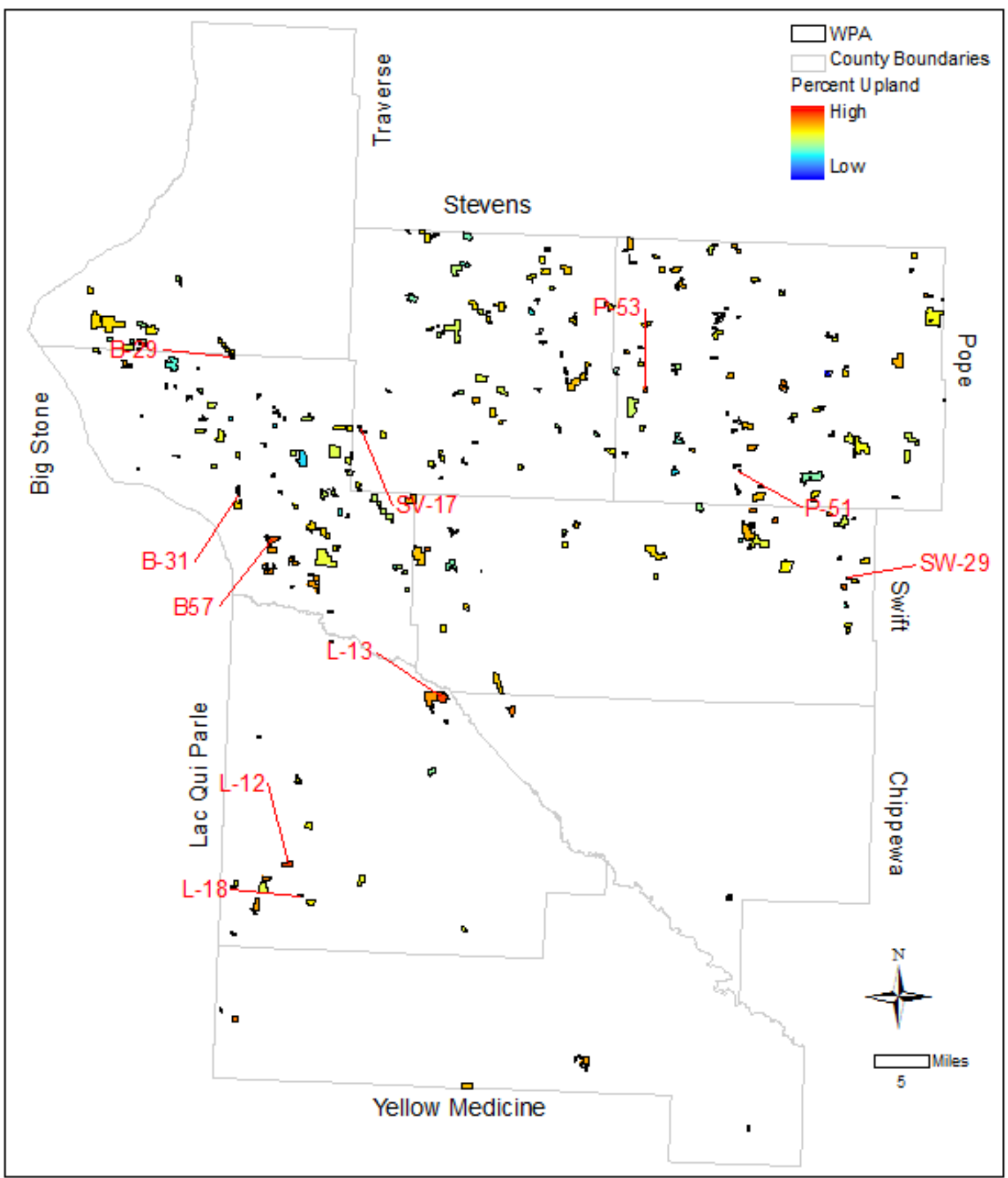

Figure 4. Percent upland habitat map. WPAs with the top 10 scores for the percent upland habitat criterion are highlighted. 
Table 6. Top ranked WPAs in terms of the percent upland habitat criterion. Percent upland values listed are before normalization (scale is 0 to $98.72 \%$ ).

\begin{tabular}{|l|l|l|c|c|}
\hline Rank & WPA ID & WPA Name & WPA Size (acres) & Percent Upland \\
\hline 1 & SV-17 & Grossman & 76.2 & 98.7 \\
\hline 2 & B-29 & Daly & 31.8 & 95.3 \\
\hline 3 & L-13 & Hegland & 463.3 & 93.1 \\
\hline 4 & L-12 & Goodman & 235.8 & 91.8 \\
\hline 5 & SW-29 & Roderick & 40.7 & 91.5 \\
\hline 6 & L-18 & Freeland & 80.0 & 91.1 \\
\hline 7 & B-31 & Moulton Lake & 133.6 & 89.9 \\
\hline 8 & B-57 & Twin Lakes & 404.6 & 89.7 \\
\hline 9 & P-53 & Barsness & 80.3 & 89.3 \\
\hline 10 & P-51 & Hanson & 40.3 & 87.7 \\
\hline
\end{tabular}

\section{Diversity of Wetland Types}

The diversity of wetland types was calculated for each WPA using the Morris WMD Habitat Layer. The habitat layer wetland features were first reclassified into four different wetland types that are based on the wetland's water regime (temporary, seasonal, semi-permanent, and permanent) (Table 7). The total number of each wetland type that occurs within each WPA was calculated. If there were greater than or equal to three different wetland types occurring within the WPA a score of 100 was given, if there were less than three wetland types a score of zero was given. Figure 5 shows the results of the diversity of wetland type analysis. A table has not been added because several WPAs have scores of 100 .

Table 7. Wetland classes from the Morris WMD Habitat Layer and corresponding wetland types used for this criterion.

\begin{tabular}{|l|l|}
\hline \multicolumn{1}{|c|}{ Habitat Layer Class } & \multicolumn{1}{|c|}{$\begin{array}{c}\text { Wetland Type } \\
\text { (water regime) }\end{array}$} \\
\hline Lake (LABF) & Permanent \\
\hline Stock Pond (PUBF) & Semi-permanent \\
\hline Wetland Type 1 (PEMA - Palustrine, Emergent, Temporary Flooded) & Temporary \\
\hline Wetland Type 2 (PEMB - Palustrine, Emergent, Saturated) & Temporary \\
\hline Wetland Type 3 (PEMC - Palustrine, Emergent, Seasonally Flooded) & Seasonal \\
\hline $\begin{array}{l}\text { Wetland Type } 4 \text { (PEMF - Palustrine, Emergent, Semipermanently } \\
\text { Flooded, PUBF - Palustrine, Unconsolidated Bottom, Semipermanently } \\
\text { Flooded) }\end{array}$ & Semi-permanent \\
\hline Wetland Type 5 (PEMH - Palustrine, Emergent, Permanently Flooded) & Permanent \\
\hline Wetland Type 6 (PSSA - Palustrine, Scrub-Shrub, Temporary Flooded) & Temporary \\
\hline
\end{tabular}




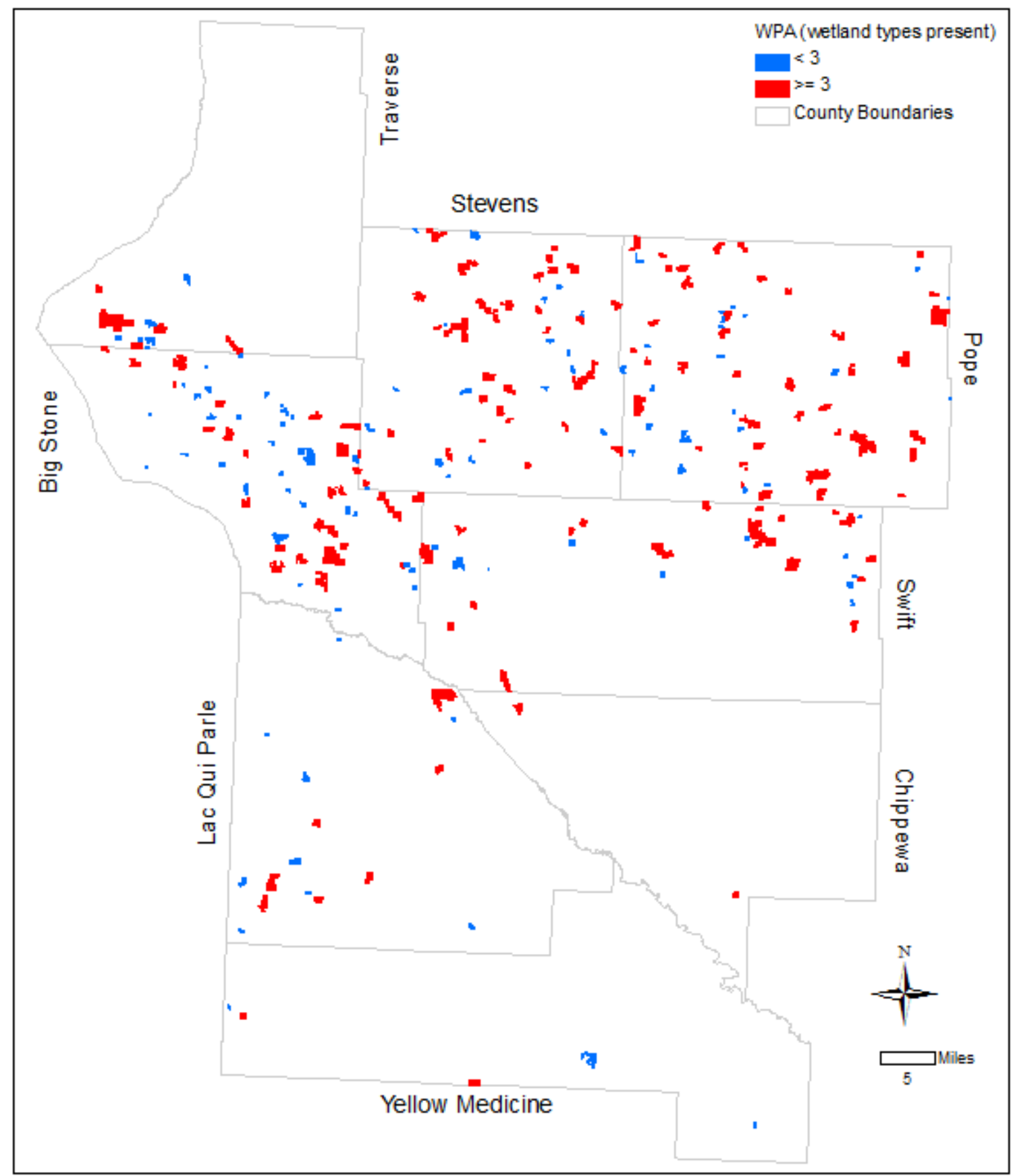

Figure 5. Wetland type diversity map

\section{WPA Complex Size}

The size of each WPA was identified using the USFWS Interest Layer. Since adjacent WPAs (WPA complex) are managed as one unit, the acres for WPAs within 25 meters of one another were consolidated. The minimum and maximum values within this data layer were 6.68 and $2,003.93$ acres. These values were normalized between a minimum score of 0 and a maximum 
score of 100 . The results of the WPA size analysis are displayed in Figure 6 and the top 10 WPAs are listed in Table 8.

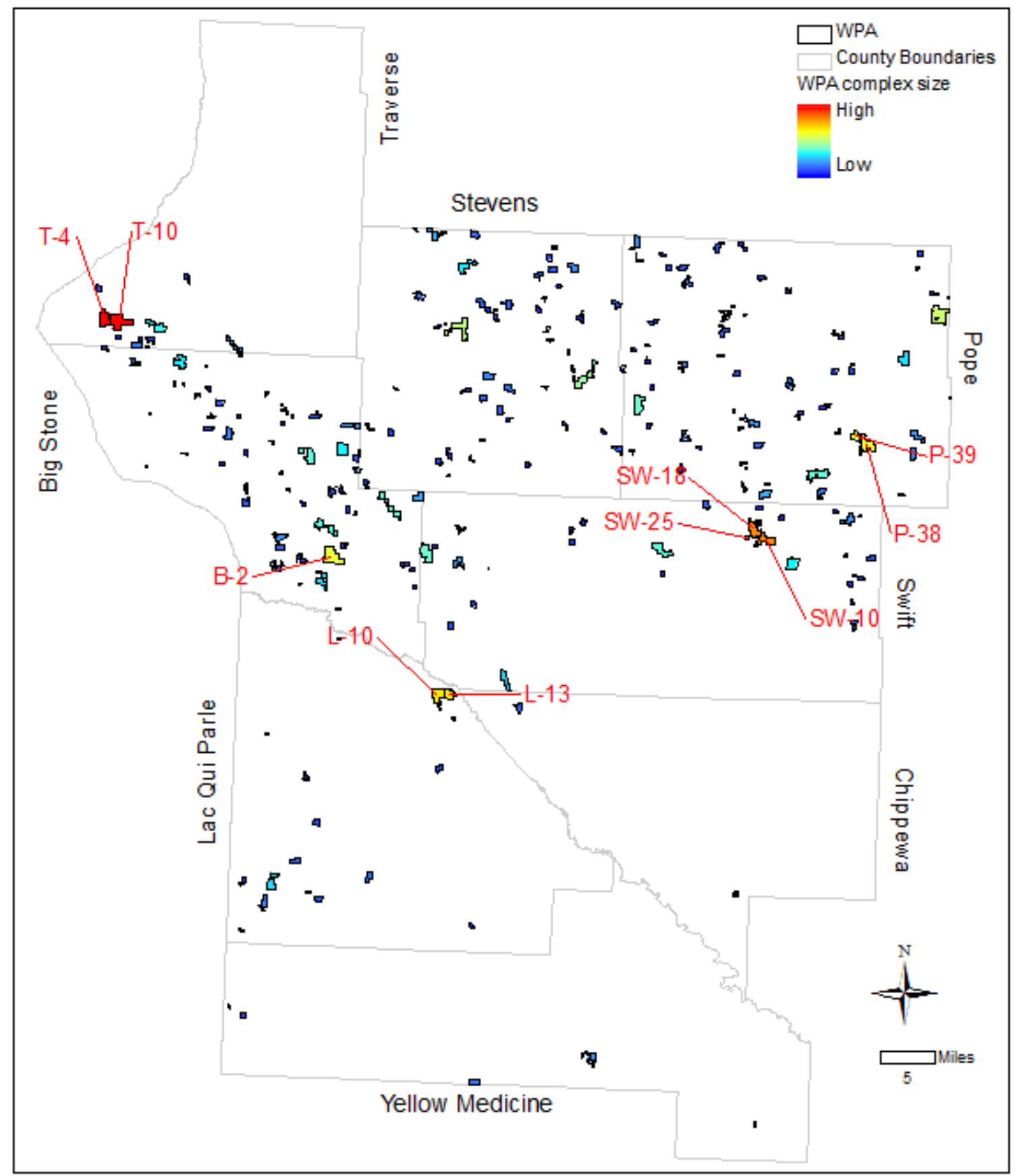

Figure 6. Waterfowl Production Area (or WPA complex) size map. The top 10 largest WPAs or WPA complexes are highlighted. 
Table 8. Top ranked WPAs in terms of the WPA complex size criterion. WPA complex acres are before normalization (scale is 6.7 to 2003.9 acres).

\begin{tabular}{|l|l|l|c|c|}
\hline Rank & $\begin{array}{l}\text { WPA } \\
\text { ID }\end{array}$ & WPA Name & WPA Size (acres) & WPA Complex Size (acres) \\
\hline 1 & T-10 & Robin Hood & 1250.9 & 2003.9 \\
\hline 2 & T-4 & Mosquito Ranch & 753.0 & 2003.9 \\
\hline 3 & SW-25 & Tolifson & 90.1 & 1675.9 \\
\hline 4 & SW-18 & Loen & 879.4 & 1675.9 \\
\hline 5 & SW-10 & Svor & 706.4 & 1675.9 \\
\hline 6 & L-10 & Hastad & 947.2 & 1410.5 \\
\hline 7 & L-13 & Hegland & 463.3 & 1410.5 \\
\hline 8 & P-39 & Overby & 313.8 & 1278.7 \\
\hline 9 & P-38 & Nelson Lake & 964.9 & 1278.7 \\
\hline 10 & B-2 & Rothi & 1232.5 & 1232.5 \\
\hline
\end{tabular}

\section{Effective Conservation Area}

The effective conservation area of each WPA given its proximity to other permanently protected lands was calculated using several data layers for conservation lands. The intent of this criterion is to identify those WPAs that have a larger effective size than the "size of the WPA" criterion. A 40 acre WPA adjacent to a 160 acre state wildlife area would have an effective size of 200 acres, and would have more potential than an isolated 40 acre WPA. Several different categories of permanent conservation lands were included in this analysis:

- $\quad$ Department of Natural Resources (DNR) Scientific and Natural Area

- $\quad$ DNR Wildlife Management Area (WMA)

- $\quad$ DNR Native Prairie Bank Program

- $\quad$ United States Department of Agriculture (USDA) Reinvest In Minnesota, Conservation Reserve Enhancement Program

- $\quad$ USDA Wetlands Reserve Program

- $\quad$ The Nature Conservancy Preserves

- $\quad$ USFWS National Wildlife Refuge System (National Wildlife Refuges (NWR) and WPAs)

- $\quad$ DNR State Park

- $\quad$ USFWS Habitat Easement (grassland, Tallgrass Prairie (NWR), and Farmers Home Administration)

The first step in developing this data layer was to merge all of the different conservation land categories together. Next, individual WPAs were selected that were within 25 meters of any other conservation land. Twenty five meters was used to represent the minimum distance allowable between two parcels of land for those parcels to be considered "adjacent". Normally, one would use a distance of zero, but using multiple data layers developed by 
numerous organizations at several scales incorporates a significant level of positional error into the analysis. A cursory examination of the distance of WPAs to the various conservation lands shows that once we set the buffer at 25 meters there was not an increase of WPAs selected when we increased the buffer distance to 30 meters (Table 9).

Table 9. Number of WPAs selected as "adjacent" to other conservation lands with increasing buffer distances.

\begin{tabular}{|l|l|}
\hline Buffer Distance (meters) & WPAs Selected \\
\hline 0 & 39 \\
\hline 5 & 57 \\
\hline 10 & 65 \\
\hline 15 & 73 \\
\hline 20 & 75 \\
\hline 25 & 76 \\
\hline 30 & 76 \\
\hline 50 & 77 \\
\hline
\end{tabular}

Next, using these selected WPAs as sources we selected all conservation lands that were within 25 meters. Then, we selected all conservation lands that were within 25 meters of these selected features. We kept doing this until no new features were selected, thus any remaining features within the district were beyond the 25 meter adjacency requirement. Potential conservation lands outside of the district boundary were investigated but none were found that were within the designated 25 meter buffer distance. Figure 7 gives a close-up example of the effective areas surrounding a few select WPAs. 


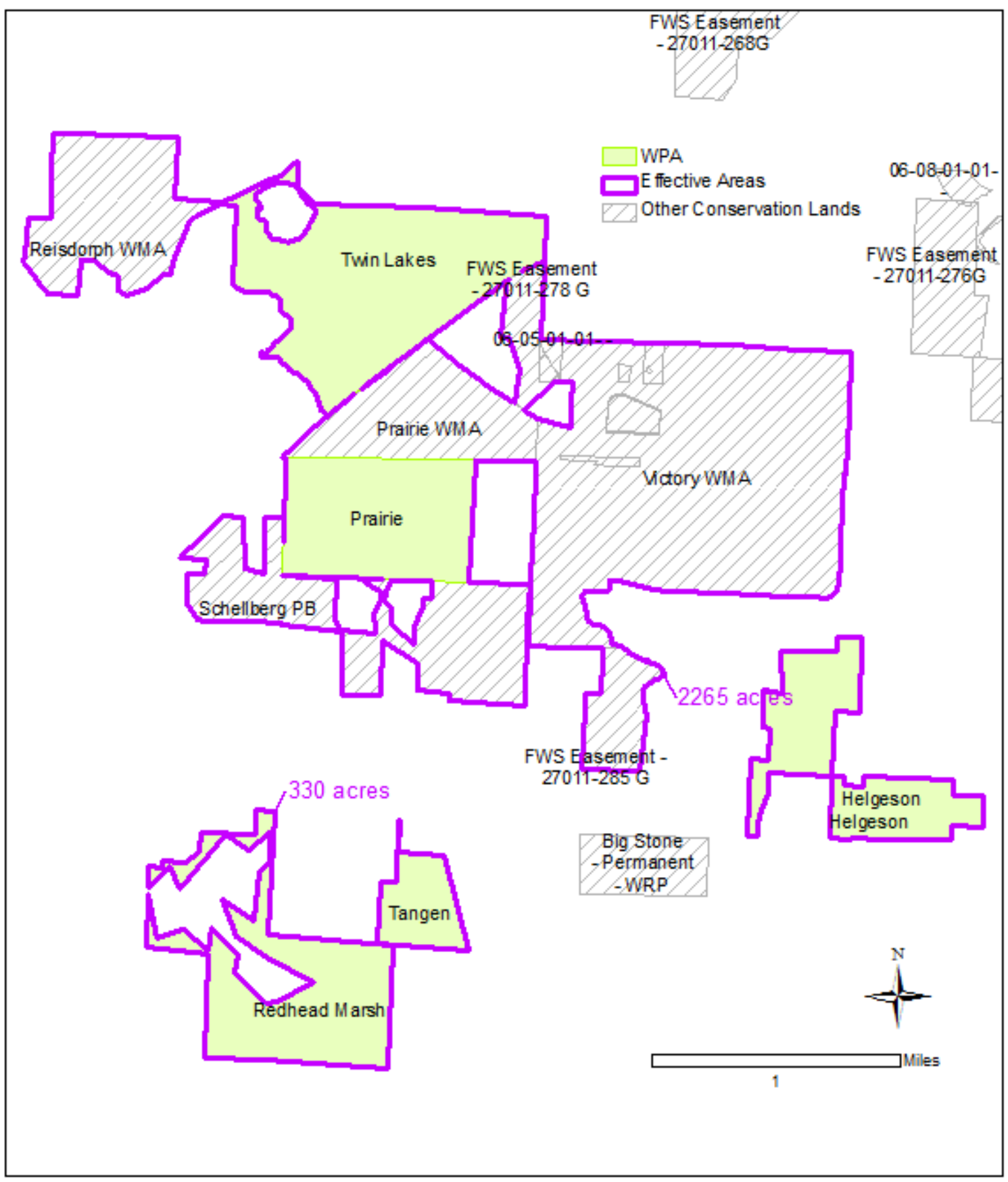

Figure 7. Close-up view of how effective areas were delineated

The total effective acres for each WPA were then calculated. The minimum and maximum number of total effective areas assigned to each WPA was 6.684 and 49,565 acres. WPAs that were not adjacent to any other conservation land were given a value equal to their size in acres. These acre values were normalized between a minimum score of 0 and a maximum score of 100. The largest effective area acreage value, 49,565, was a significant outlier (Lac qui Parle WMA/Big Stone NWR complex) so the next largest value $(2,839.8$ acres) was used as the maximum and all other values were scaled from that point of reference. Therefore, anything $2,839.8$ or greater acres were given a 100 value in the model and all other values were 
normalized from 2,839.8 acres. Effective conservation areas are shown in Figure 8 and the top ranked WPAs are listed in Table 10.

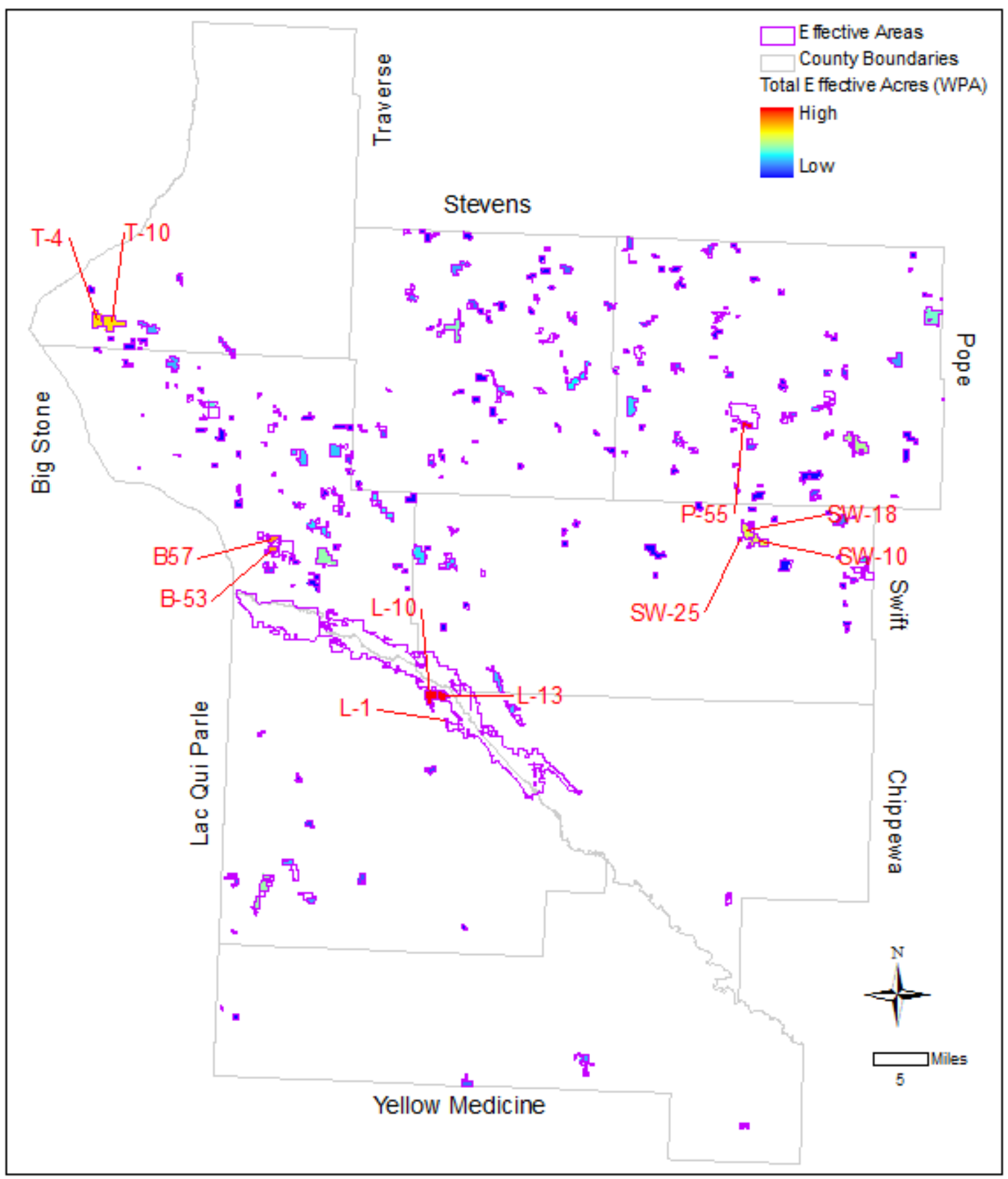

Figure 8. Effective conservation area map. WPAs with the top 10 largest effective conservation areas are highlighted. 
Table 10. Top ranked WPAs in terms of the effective conservation area criterion. Effective acres listed are before normalization (scale is 6.7 to $49,565.4$ acres).

\begin{tabular}{|l|l|l|c|c|}
\hline Rank & WPA ID & WPA Name & WPA Size (acres) & Effective Area (acres) \\
\hline 1 & L-10 & Hastad & 947.2 & $49,565.4$ \\
\hline 2 & L-13 & Hegland & 463.3 & $49,565.4$ \\
\hline 3 & L-1 & Borass & 40.3 & $49,565.4$ \\
\hline 4 & P-55 & Blue Mounds & 392.8 & $2,839.8$ \\
\hline 5 & B-57 & Twin Lakes & 404.6 & $2,265.2$ \\
\hline 6 & B-53 & Prairie & 237.5 & $2,265.2$ \\
\hline 7 & T-10 & Robin Hood & 1250.9 & $2,016.5$ \\
\hline 8 & T-4 & Mosquito Ranch & 753.0 & $2,016.5$ \\
\hline 9 & SW-18 & Loen & 879.4 & $1,675.8$ \\
\hline 10 & SW-10 & Svor & 706.4 & $1,675.8$ \\
\hline 11 & SW-25 & Tolifson & 90.1 & $1,675.8$ \\
\hline
\end{tabular}

\section{Remnant Prairie Size}

The size of each WPA's remnant prairie was then calculated. This represents the total acreage of all area within the WPA classified as "'Grass_Native_Prairie" in the Morris WMD Habitat Layer. The minimum and maximum values within this data layer were 0 and 634.99 acres, and these values were normalized between a minimum score of 0 and a maximum score of 100 . Figure 9 depicts the relative remnant prairie size on WPAs and Table 11 lists the top 10 WPAs for this criterion. 


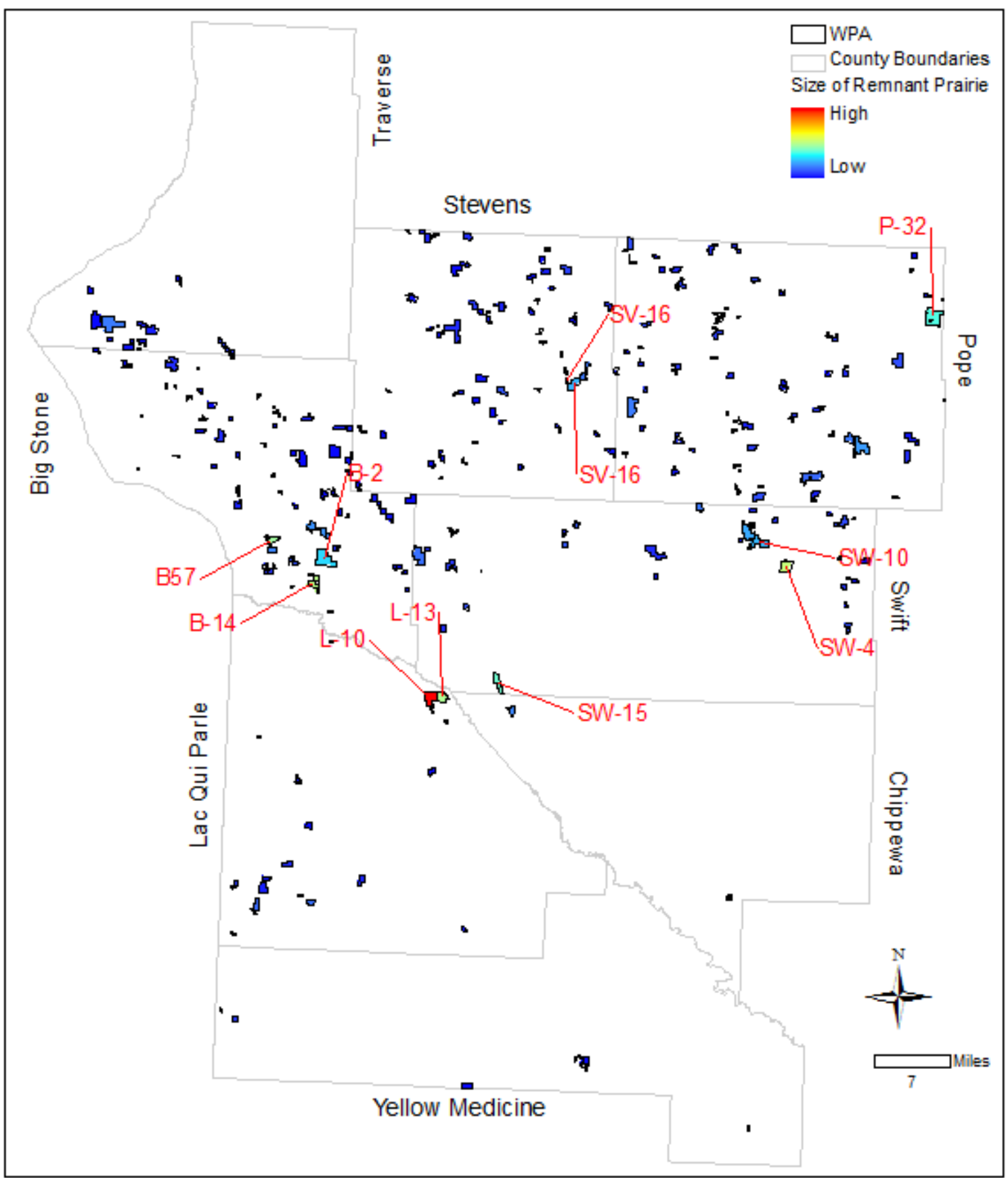

Figure 9. Remnant prairie size map. WPAs with the top ten amounts of remnant prairie are highlighted. 
Table 11. Top ranked WPAs in terms of native prairie size criterion. Values for acres of native prairie are before normalization (scale is 0.00 to 634.99 acres).

\begin{tabular}{|l|l|l|c|c|}
\hline Rank & WPA ID & WPA Name & WPA Size (acres) & Remnant Prairie Size (acres) \\
\hline 1 & L-10 & Hastad & 947.2 & 635.0 \\
\hline 2 & SW-4 & Welsh & 661.3 & 339.6 \\
\hline 3 & B-14 & Hillman & 572.2 & 323.1 \\
\hline 4 & L-13 & Hegland & 463.3 & 312.2 \\
\hline 5 & B-57 & Twin Lakes & 404.6 & 297.3 \\
\hline 6 & SW-15 & Appleton & 560.1 & 250.9 \\
\hline 7 & P-32 & Krantz Lake & 1110.7 & 237.8 \\
\hline 8 & B-2 & Rothi & 1232.5 & 180.8 \\
\hline 9 & SW-10 & Svor & 706.4 & 153.3 \\
\hline 10 & SV-16 & Edwards & 545.7 & 148.6 \\
\hline
\end{tabular}

\section{Proximity to Human Development}

The distance from human developments can influence wildlife; some species (e.g., prairie chickens) seem to avoid human activity, while others may be more abundant near human developments (e.g., raccoons). The proximity to human developments can also affect management logistics, particularly relative to smoke control in prescribed fire.

We created an input layer to represent proximity to human development using both major roads and cities as human development sources. This input layer involved calculating the Euclidian distance from several feature types associated with human development out to two miles. Cells that are two miles or more from development were given a score of 100 . Cells within the two mile buffer were given a model score based upon their relative distance from the development feature. The proximity to human development scores are depicted spatially in Figure 10, but a summary table of highest ranked WPAs has not been added because several have scores of 100. 


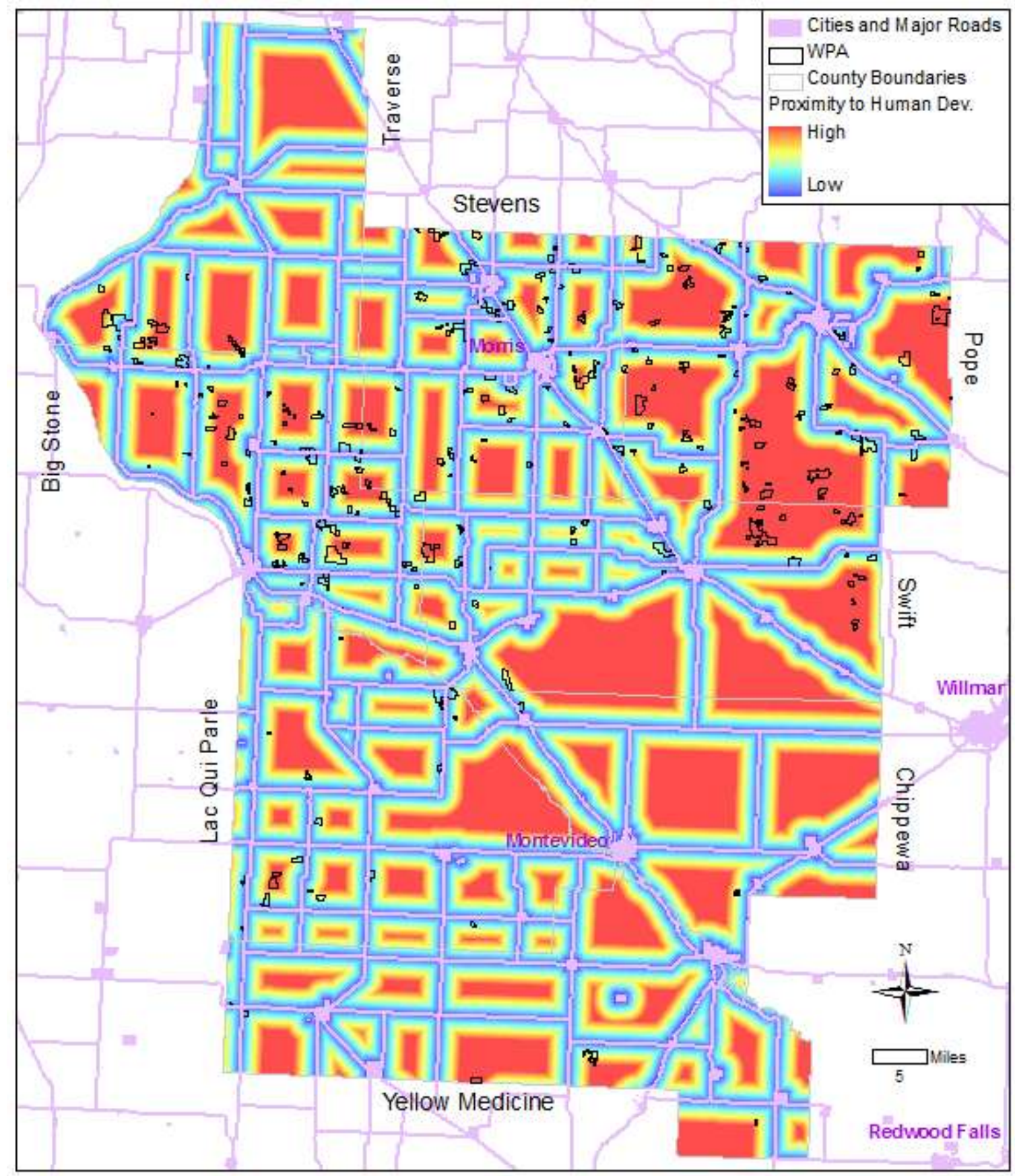

Figure 10. Proximity to human development map. A low value indicates a closer proximity to human development.

\section{Grassland Bird Suitability}

The suitability of a WPA's landscape for grassland birds was identified using a spatial data set developed by HAPET. Their landscape models for grassland birds were based on point count data collected in 2003-2005 (Quamen 2007). A variety of regression methods were used to model bird density (bird detections/ha) for Sedge Wren, Clay-colored Sparrow, Grasshopper 
Sparrow, Le Conte's Sparrow, Savannah Sparrow, Bobolink, Dickcissel, and Western Meadowlark. Models were mapped by applying regression equations to grids of percent cover and BBS relative abundance (used as a spatial covariate to account for species range), and limited to grass areas $>1$ ha. For models that predicted the number of pairs, the total number of pairs per 40 acres was predicted by calculating the pairs predicted for the grass portion of each 40 acre cell. Maps were 'smoothed' by taking the average predicted pairs in a 40 acre cell for a 1-mile radius (U.S. Fish and Wildlife Service, n.d.c).

Although species models differed by landscape scale and specific landscape variables, the resulting maps were similar. To summarize and simplify, the total predicted number of pairs was summed for Sedge Wren, Grasshopper Sparrow, Le Conte's Sparrow, Savannah Sparrow, Bobolink, and Dickcissel. Clay-colored Sparrows were not included because of numerical issues in estimating the model (see Quamen 2007); Western Meadowlarks were not included because the logistic regression model used predicts probability of presence, not number of pairs. Because all species models improved with the inclusion of local variables, landscape models depict the potential for breeding pairs where suitable local habitat exists (U.S. Fish and Wildlife Service, n.d.c).

The data were received as a raster data set with 40 acre cells. To make the data useable within the tool it first needed to be converted to a raster with 50 meter $\times 50$ meter cells. This was again accomplished using the focalstatistics tool and each cell was again reattributed according to the average value of all 50 meter $\times 50$ meter cells within a rectangle 400 meters $\times 400$ meters. The minimum and maximum values within this data layer were 0 and 52 nesting grassland bird pairs/40 acres. These values were normalized between a minimum score of 0 and a maximum score of 100 . The modified grassland bird suitability model is shown in Figure 11. The top ranking WPAs for this criterion are listed in Table 12. 


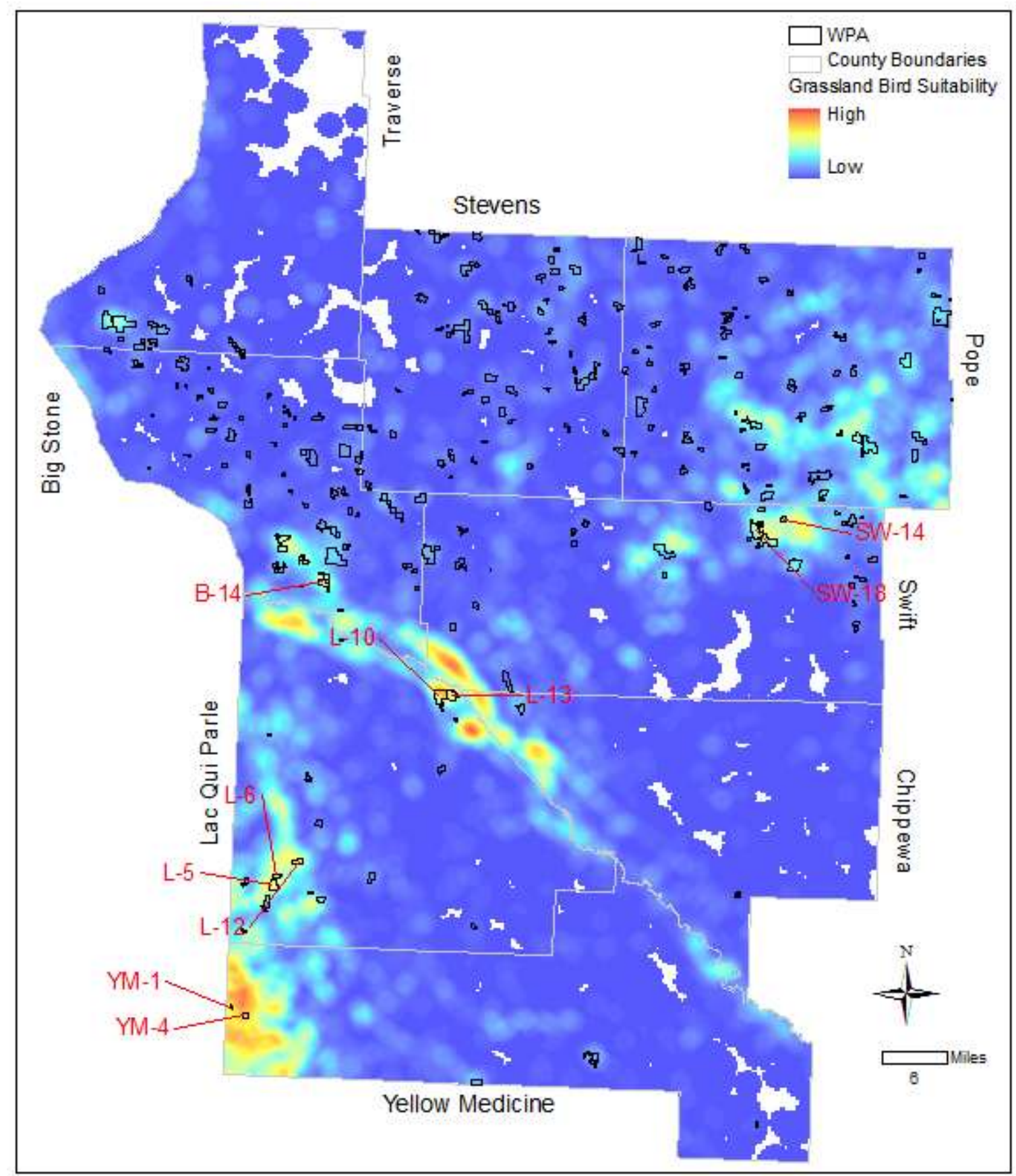

Figure 11. Modified grassland bird suitability map. WPAs with the top 10 mean scores for the grassland bird suitability criterion are highlighted. 
Table 12. Top ranked WPAs in terms of the grassland bird suitability criterion. The mean score listed is before normalization (scale is 0 to $\mathbf{5 2}$ grassland bird nesting pairs/40 acres).

\begin{tabular}{|l|l|l|c|c|}
\hline Rank & WPA ID & WPA Name & $\begin{array}{l}\text { WPA Size } \\
\text { (acres) }\end{array}$ & $\begin{array}{l}\text { Mean Grassland Bird Suitability } \\
\text { Score }\end{array}$ \\
\hline 1 & YM-4 & Dakota & 150.8 & 39.3 \\
\hline 2 & YM-1 & Kontz & 26.5 & 36.4 \\
\hline 3 & L-13 & Hegland & 463.3 & 31.6 \\
\hline 4 & L-10 & Hastad & 947.2 & 31.4 \\
\hline 5 & L-5 & Farrell & 400.6 & 29.2 \\
\hline 6 & L-12 & Goodman & 235.8 & 29.1 \\
\hline 7 & L-6 & Bolson & 178.7 & 26.1 \\
\hline 8 & SW-14 & Swift Falls & 121.4 & 22.9 \\
\hline 9 & B-14 & Hillman & 572.2 & 22.3 \\
\hline 10 & SW-18 & Loen & 879.4 & 22.3 \\
\hline
\end{tabular}

\section{Percentage of Wetlands Non-drained (Natural)}

The non-drained wetland input variable was calculated for each WPA using data produced by the USFWS National Wetland Inventory. Each polygon representing a wetland is giving an attribute code. If the special modifier " $d$ " is used, the wetland has at some time been partly drained or ditched. For this analysis, we created a new layer which separated all polygons as to whether they had this modifier or not. Next, we intersected this data set with the WPA data set to ascertain the percentage of wetland area within the WPA that was classified as nondrained (natural). A table has not been added because several have scores of 100; the percent of undrained wetland area on WPAs is displayed in Figure 12. 


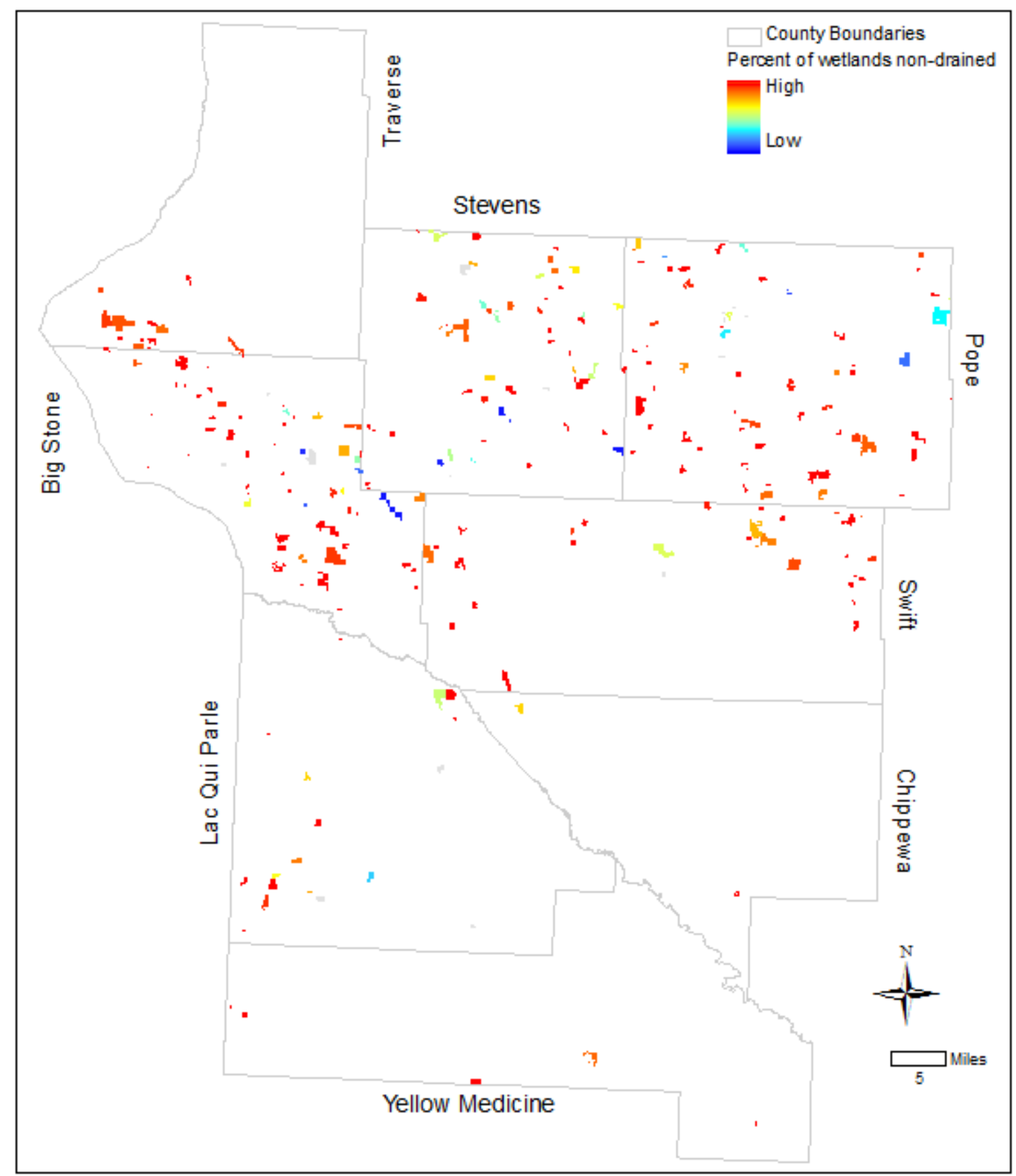

Figure 12. Percent of wetland area on each WPA that is non-drained.

\section{Models}

After assembling and reclassifying each of the individual input data layers described above, we developed "Objective Models" to rank WPAs for each of the five station objectives (breeding waterfowl, grassland birds, tallgrass prairie, prairie wetlands, and threatened and endangered species). The criteria and associated weights for each objective model were identified at the December 2009 workshop and in subsequent discussions with Morris WMD staff. 
A single integrated model was also built, which combined the five input objective models.

The models were built using a system of weighted overlays. The input data layers (i.e., prioritization criteria) were overlaid and the scores for a particular location were averaged using designated model influence percentages (weights) as a modifier. Higher weights were given to those data layers that were considered higher priority.

Figure 13 illustrates the weighted overlay process. For each input variable, the value calculated for that WPA was multiplied by the designated weight for that variable. In the case of the percent upland variable, Hastad WPA had a normalized score of 82.03 (a), this was then multiplied by 0.16 (b) the weight (percent) specified by the model scorers. The result (c) was then added for each variable to get the final output score. In the case of the Grassland Birds Model for Hastad WPA, this was calculated to be 74.56 .

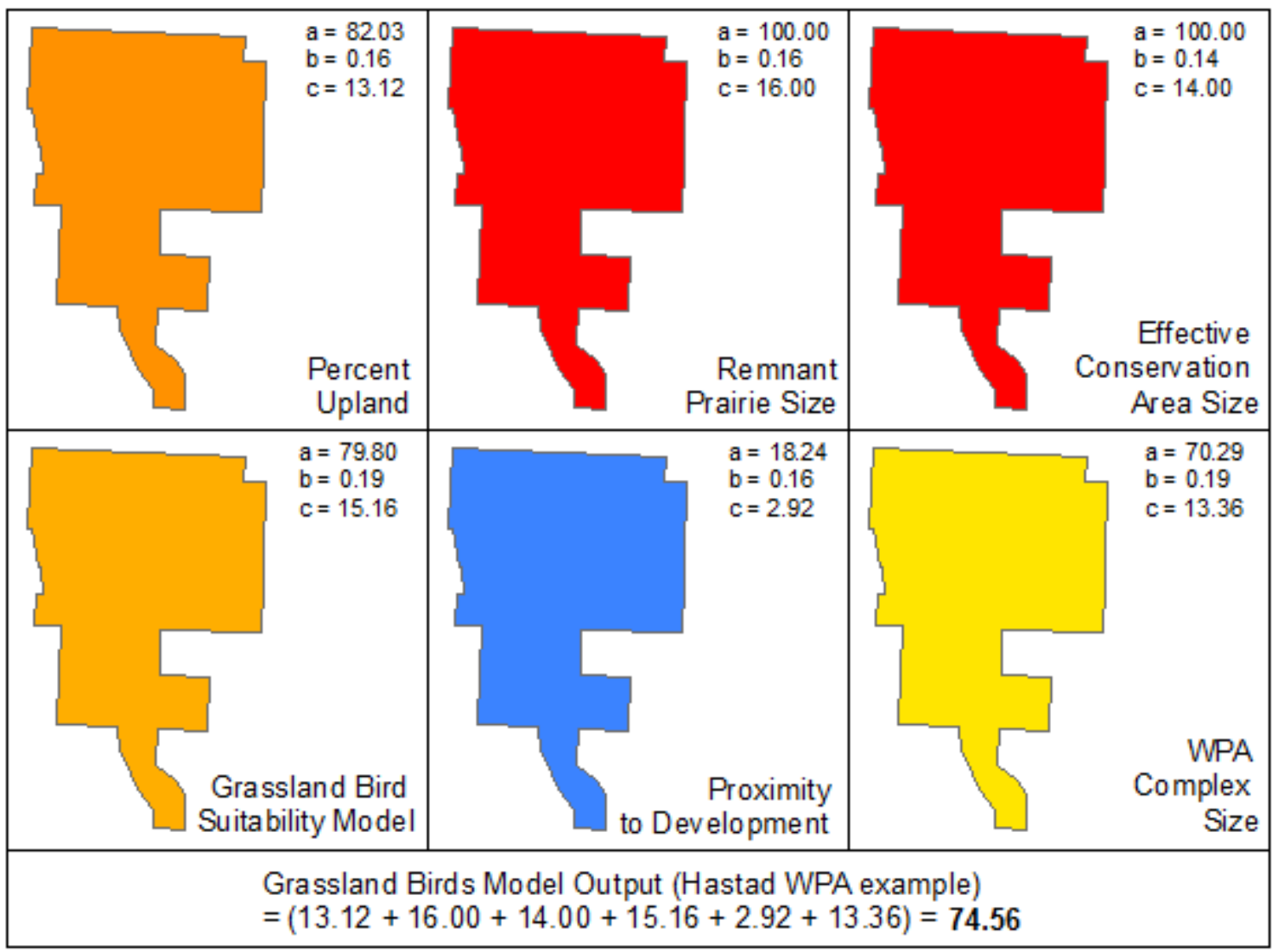

Figure 13. Diagram depicting how weighted overlay functions

The details of each model, including the relative importance (weights) of the criteria used to build them, are described in the sections below. For each model, we include a district map showing the relative model scores for each WPA and a table listing the top-ranked WPAs. Full results of the analyses are in Appendix 2 and are also available in a sortable format at the following web site: http://umesc-gisdb03.er.usgs.gov/morris wmd/wpa priority.htm. 


\section{Breeding Waterfowl Objective Model}

Waterfowl production areas are purchased with revenues from the sale of Migratory Bird Hunting and Conservation Stamps (Duck Stamps), and as such their primary purpose is to provide breeding waterfowl habitat. This model uses eight criteria that we felt were most relevant for ranking WPAs in regard to their relative potential for waterfowl production (Table 13). The relative breeding waterfowl scores for each WPA are depicted in Figure 14, and Table 14 lists the top ranked WPAs for waterfowl production potential.

Table 13. Breeding waterfowl model input criteria

\begin{tabular}{|c|c|c|}
\hline Criteria & Justification & Weight \\
\hline Duck pair potential & Ducks are attracted to a landscape with many wetlands & 17 \\
\hline Percent grass & $\begin{array}{l}\text { Ducks have higher nest success in landscapes with } \\
\text { more grass }\end{array}$ & 17 \\
\hline Percent upland habitat & $\begin{array}{l}\text { Breeding requirements for waterfowl include a balance } \\
\text { of upland nesting cover and wetland habitat on the } \\
\text { WPA; Small Wetland Acquisition Program delineation } \\
\text { guidelines encourage } \geq 4: 1 \text { upland to wetland ratio } \\
\text { ( } 80 \% \text { upland) }\end{array}$ & 12 \\
\hline $\begin{array}{l}\text { Diversity of wetland } \\
\text { types }\end{array}$ & $\begin{array}{l}\text { Ducks use a diversity of wetland types during the } \\
\text { breeding season }\end{array}$ & 8 \\
\hline $\begin{array}{l}\text { Effective conservation } \\
\text { area }\end{array}$ & Increases overall habitat base & 12 \\
\hline WPA size & $\begin{array}{l}\text { Increases overall habitat base for which we have } \\
\text { management authority }\end{array}$ & 14 \\
\hline Remnant prairie size & & 8 \\
\hline \multirow{2}{*}{$\begin{array}{l}\text { Proximity to human } \\
\text { development }\end{array}$} & & 12 \\
\hline & Total & 100 \\
\hline
\end{tabular}




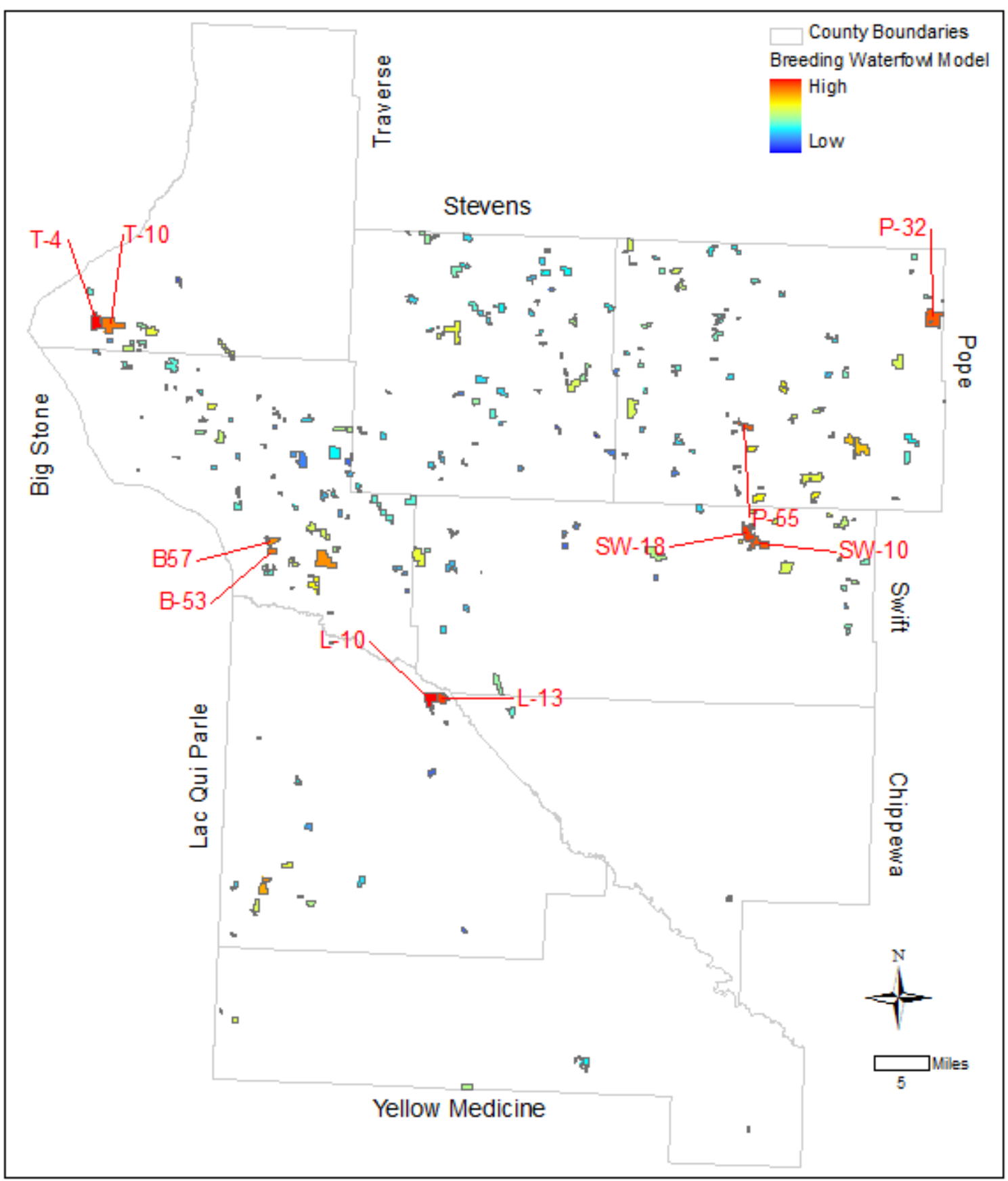

Figure 14. Breeding waterfowl model output map. WPAs with the top 10 scores for this model are highlighted. 
Table 14. Top ranked WPAs in terms of mean breeding waterfowl score

\begin{tabular}{|l|l|l|c|c|}
\hline Rank & WPA ID & WPA Name & WPA Size (acres) & Mean Breeding Waterfowl Score \\
\hline 1 & T-4 & $\begin{array}{l}\text { Mosquito } \\
\text { Ranch }\end{array}$ & 753.0 & 68.3 \\
\hline 2 & L-10 & Hastad & 947.2 & 67.3 \\
\hline 3 & L-13 & Hegland & 463.3 & 65.8 \\
\hline 4 & SW-18 & Loen & 879.4 & 64.2 \\
\hline 5 & SW-10 & Svor & 706.4 & 63.4 \\
\hline 6 & P-32 & Krantz Lake & 1110.7 & 62.4 \\
\hline 7 & P-55 & Blue & 392.8 & 61.9 \\
\hline 8 & Mounds & & 61.1 \\
\hline 9 & B-53 & Robin Hood & 1250.9 & 60.4 \\
\hline 10 & B-57 & Twin Lakes & 404.6 & 58.7 \\
\hline
\end{tabular}

\section{Grassland Bird Objective Model}

The Fish and Wildlife Service is entrusted with conserving and protecting migratory birds.

While WPAs were established to provide habitat for breeding waterfowl, another priority group of migratory birds at Morris WMD are grassland birds. Most populations of grasslanddependent birds are in steep decline across their ranges (Sauer and others 2008). We identified six criteria that would be important for ranking WPAs based on their potential to support grassland birds (Table 15). Figure 15 depicts the results of the grassland bird model by WPA, while Table 16 shows the top ranked WPAs for grassland birds. 
Table 15. Grassland bird model input criteria

\begin{tabular}{|c|c|c|}
\hline Criteria & Justification & Weight \\
\hline Grassland bird suitability & $\begin{array}{l}\text { HAPET has developed several habitat suitability } \\
\text { models for grassland birds }\end{array}$ & 19 \\
\hline Percent upland habitat & $\begin{array}{l}\text { Wetlands can essentially fragment the upland habitat } \\
\text { required by grassland birds; a ratio of } 8: 1 \text { upland to } \\
\text { wetland habitat ( } 89 \% \text { upland) would favor many } \\
\text { grassland birds (Diane Granfors, personal } \\
\text { communication 2010) }\end{array}$ & 16 \\
\hline $\begin{array}{l}\text { Effective conservation } \\
\text { area }\end{array}$ & Increases overall habitat base & 14 \\
\hline WPA size & $\begin{array}{l}\text { Increases overall habitat base for which we have } \\
\text { management control }\end{array}$ & 19 \\
\hline Remnant prairie size & $\begin{array}{l}\text { Remnant prairie is more likely to have the } \\
\text { microhabitats required by grassland birds than would } \\
\text { be found in typical planted grasslands }\end{array}$ & 16 \\
\hline \multirow[t]{2}{*}{$\begin{array}{l}\text { Proximity to human } \\
\text { development }\end{array}$} & Some species are sensitive to human development & 16 \\
\hline & Total & 100 \\
\hline
\end{tabular}




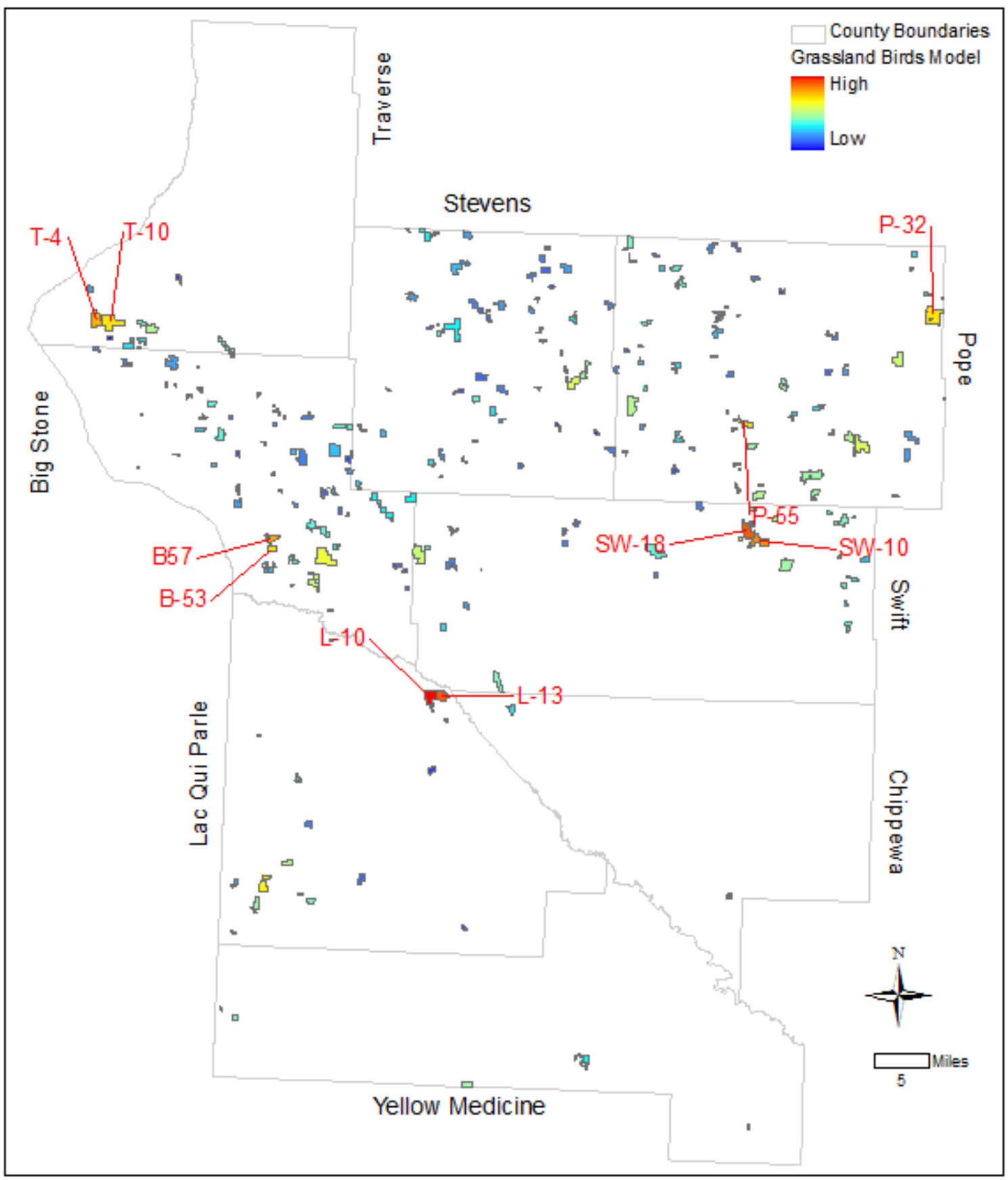

Figure 15. Grassland bird model map. WPAs with the top 10 scores for this model are highlighted. 
Table 16. Top ranked WPAs in terms of mean grassland bird model score

\begin{tabular}{|l|l|l|c|c|}
\hline Rank & WPA ID & WPA Name & WPA Size (acres) & Mean Grassland Bird Score \\
\hline 1 & L-10 & Hastad & 947.2 & 74.6 \\
\hline 2 & L-13 & Hegland & 463.3 & 68.5 \\
\hline 3 & SW-18 & Loen & 879.4 & 66.7 \\
\hline 4 & SW-10 & Svor & 706.4 & 63.7 \\
\hline 5 & T-4 & Mosquito Ranch & 753.0 & 60.9 \\
\hline 6 & B-57 & Twin Lakes & 404.6 & 60.7 \\
\hline 7 & B-53 & Prairie & 237.5 & 54.9 \\
\hline 8 & T-10 & Robin Hood & 1250.9 & 54.8 \\
\hline 9 & P-55 & Blue Mounds & 392.8 & 54.8 \\
\hline 10 & P-32 & Krantz Lake & 1110.7 & 54.4 \\
\hline
\end{tabular}

\section{Tallgrass Prairie Objective Model}

In addition to managing for trust species (e.g., migratory birds), refuges support elements of biological diversity including invertebrates, rare plants, unique natural communities, and ecological processes that contribute to biological integrity and environmental health at the refuge, ecosystem, and regional scales. The tallgrass prairie ecosystem has seen a greater decline in area than any other major North American ecosystem; Minnesota alone has less than $1 \%$ of its original tallgrass prairie remaining (Samson and Knopf, 1994). Remaining prairie is often fragmented and degraded due to encroachment by invasive cool-season grasses and trees.

Lands managed by Morris WMD include over 7,000 acres of remnant tallgrass prairie. We identified four criteria that were important to prioritize WPAs based on their value for the tallgrass prairie ecosystem (Table 17). Figure 16 depicts the results of the tallgrass prairie model for the whole district, and Table 18 lists the top 10 ranked WPAs in terms of tallgrass prairie potential. 
Table 17. Tallgrass prairie model input criteria

\begin{tabular}{|l|l|c|}
\hline Criteria & Justification & Weight \\
\hline Percent grass & $\begin{array}{l}\text { Assume a better return if we manage a } \\
\text { remnant in the context of a more intact } \\
\text { grassland landscape }\end{array}$ & 22 \\
\hline Effective conservation area & Increases overall habitat base & 30 \\
\hline WPA size & $\begin{array}{l}\text { Increases overall habitat base for which we } \\
\text { have management control }\end{array}$ & 30 \\
\hline Remnant prairie size & $\begin{array}{l}\text { Remnant prairie is very rare and we want to } \\
\text { pay special attention to areas with larger } \\
\text { remnants }\end{array}$ & 100 \\
\hline
\end{tabular}




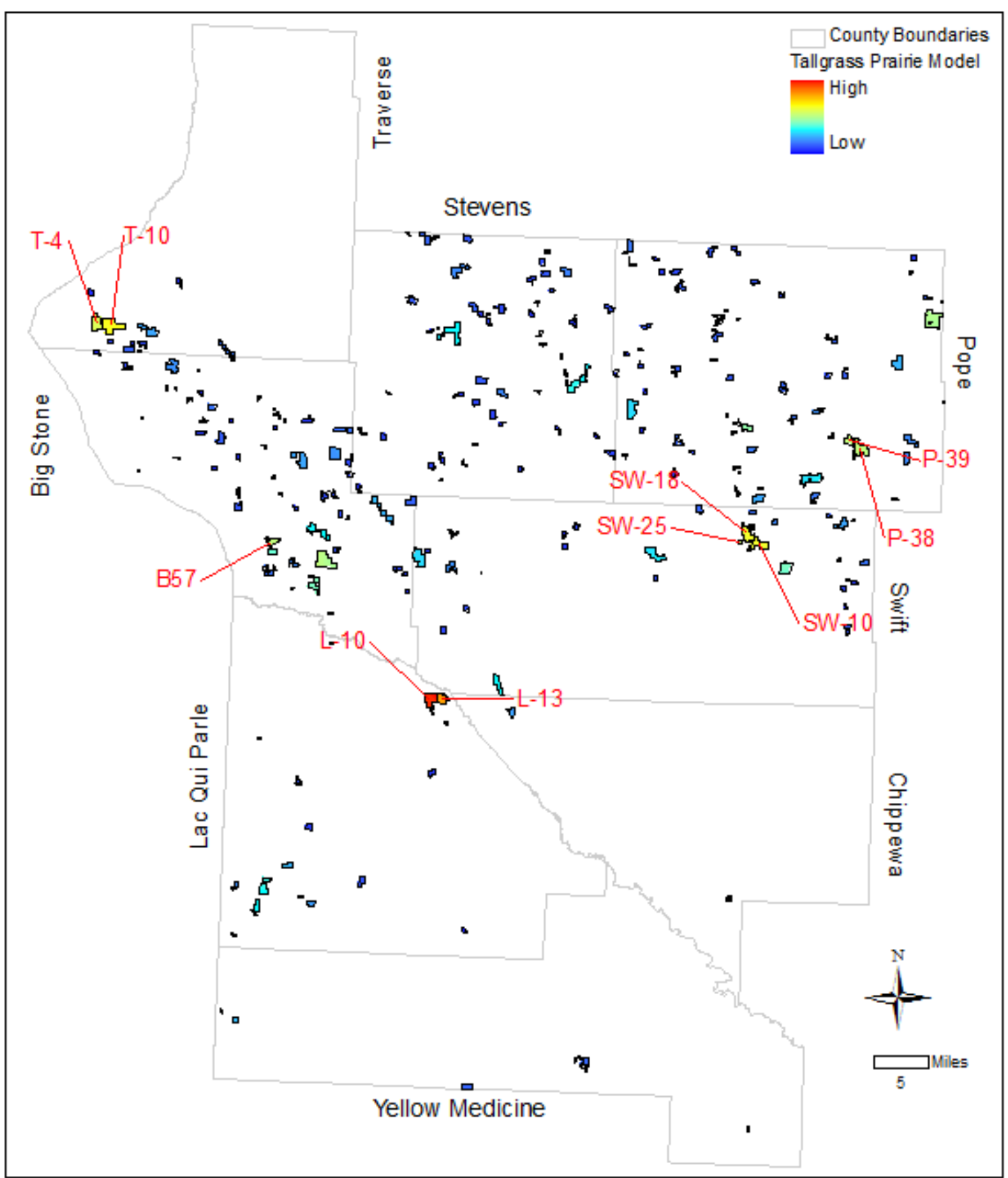

Figure 16. Tallgrass prairie model output map. WPAs with the top 10 scores for this model are highlighted. 
Table 18. Top ranked WPAs in terms of mean tallgrass prairie model score

\begin{tabular}{|l|l|l|c|c|}
\hline Rank & WPA ID & WPA Name & WPA Size (acres) & Mean Tallgrass Prairie Score \\
\hline 1 & L-10 & Hastad & 947.2 & 83.4 \\
\hline 2 & L-13 & Hegland & 463.3 & 70.9 \\
\hline 3 & T-10 & Robin Hood & 1250.9 & 55.9 \\
\hline 4 & SW-18 & Loen & 879.4 & 54.8 \\
\hline 5 & SW-10 & Svor & 706.4 & 54.8 \\
\hline 6 & T-4 & Mosquito Ranch & 753.0 & 50.0 \\
\hline 7 & P-39 & Overby & 313.8 & 45.9 \\
\hline 8 & SW-25 & Tolifson & 90.1 & 45.8 \\
\hline 9 & P-38 & Nelson Lake & 964.9 & 45.7 \\
\hline 10 & B-57 & Twin Lakes & 404.6 & 44.6 \\
\hline
\end{tabular}

\section{Prairie Wetland Ecosystem Objective Model}

Like remnant tallgrass prairie, prairie wetlands have undergone dramatic losses in Minnesota. (Johnson and others 2008) estimate that $85 \%$ of Minnesota's prairie pothole wetlands have been drained. In the Morris WMD specifically, about $50 \%$ of the wetland acres, and about $90 \%$ of individual wetland basins were drained. When they do remain, wetlands are often in a highly degraded state due to altered hydrology in the surrounding landscape and invasive species.

Table 19 lists the four criteria that we used to prioritize WPAs based on their value to the prairie wetland ecosystem. It was surprisingly difficult to find adequate criteria to use for this model. One major gap is that we do not have a good spatial data set to describe "natural" wetlands that were never drained, comparable to the layers that are available for remnant prairie that had never been plowed. Figure 17 depicts the district-wide results of the prairie wetland ecosystem model and Table 20 lists the top 10 ranked WPAs in terms of prairie wetland ecosystem potential. 
Table 19. Prairie wetland ecosystem model input criteria

\begin{tabular}{|l|l|c|}
\hline Criteria & Justification & Weight \\
\hline Diversity of wetland types & $\begin{array}{l}\text { Individual prairie wetlands function better } \\
\text { when they are in the context of a complex of } \\
\text { different wetland types }\end{array}$ & 30 \\
\hline Effective conservation area & Increases overall habitat base & 22 \\
\hline WPA size & $\begin{array}{l}\text { Increases overall habitat base for which we } \\
\text { have management control }\end{array}$ & 30 \\
\hline $\begin{array}{l}\text { Percentage of wetlands non- } \\
\text { drained (natural) }\end{array}$ & $\begin{array}{l}\text { Natural wetlands have inherent value, and are } \\
\text { more likely to have an intact plant community } \\
\text { and hydrology }\end{array}$ & 100 \\
\hline
\end{tabular}




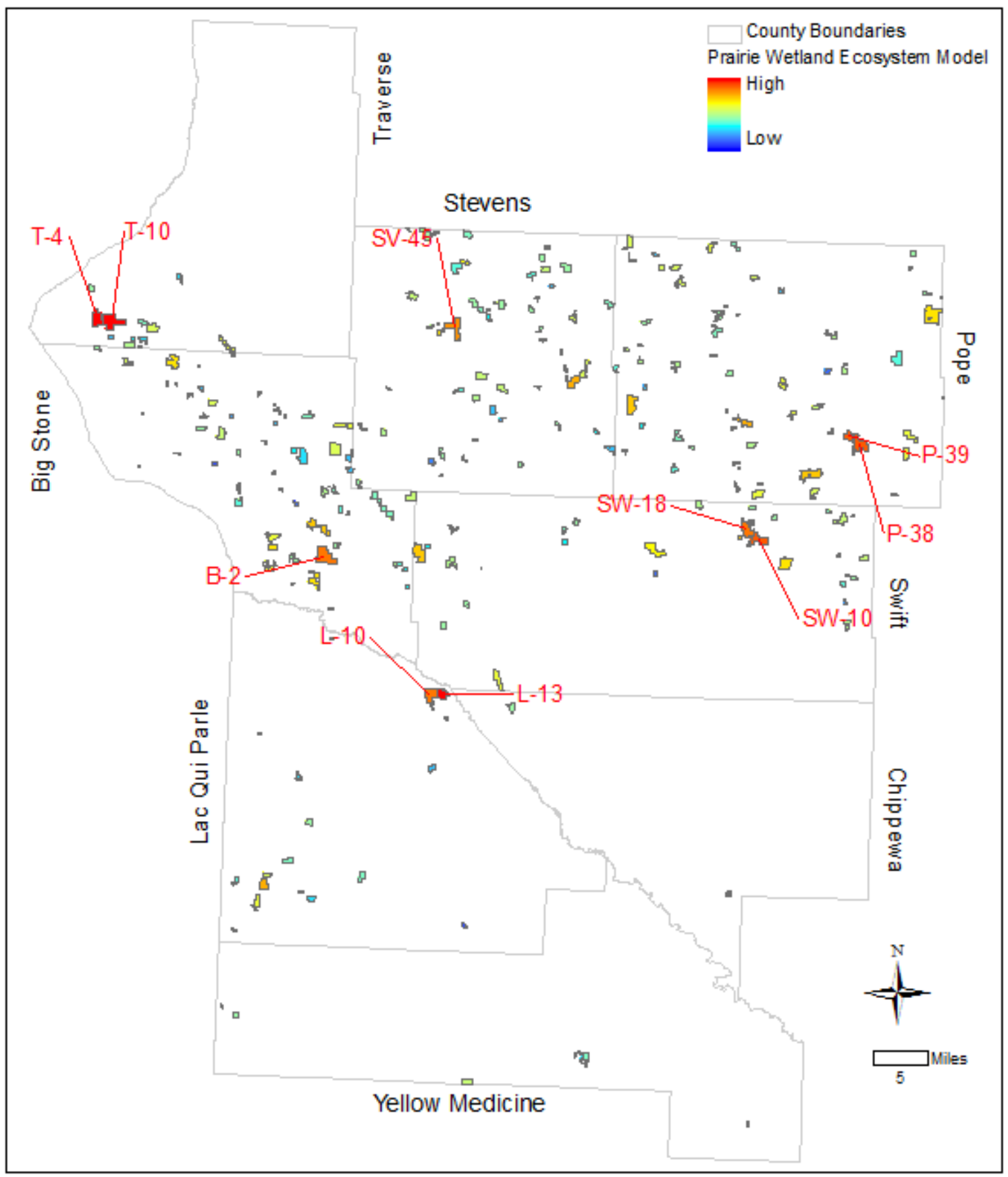

Figure 17. Prairie wetland ecosystem model output map. WPAs with the top 10 scores for this model are highlighted. 
Table 20. Top ranked WPAs in terms of mean prairie wetland ecosystem model score

\begin{tabular}{|l|l|l|c|c|}
\hline Rank & WPA ID & WPA Name & WPA Size (acres) & $\begin{array}{c}\text { Mean Prairie Wetland } \\
\text { Ecosystem Score }\end{array}$ \\
\hline 1 & T-4 & Mosquito Ranch & 753.0 & 85.2 \\
\hline 2 & T-10 & Robin Hood & 1250.9 & 84.7 \\
\hline 3 & L-13 & Hegland & 463.3 & 83.6 \\
\hline 4 & P-39 & Overby & 313.8 & 76.9 \\
\hline 5 & P-38 & Nelson Lake & 964.9 & 76.0 \\
\hline 6 & SW-10 & Svor & 706.4 & 76.0 \\
\hline 7 & B-2 & Rothi & 1232.5 & 75.3 \\
\hline 8 & L-10 & Hastad & 947.2 & 74.1 \\
\hline 9 & SW-18 & Loen & 879.4 & 71.4 \\
\hline 10 & SV-45 & Pepperton & 918.0 & \\
\hline
\end{tabular}

\section{Threatened and Endangered Species Objective Model}

In addition to migratory birds, the other USFWS trust species that Morris WMD can support are threatened and endangered species. The Natural Heritage Information System (NHIS) provides information on Minnesota's rare plants, animals, native plant communities, and other rare features. The NHIS is continually updated as new information becomes available, and is the most complete source of data on Minnesota's rare or otherwise significant species, native plant communities, and other natural features (Minnesota Department of Natural Resources, n.d.).

We created a threatened and endangered species model by first selecting those species occurrences (points) from the NHIS that had a designation of endangered or threatened (both Federal and State) and were within 1 mile of a WPA. There were 12 species that met these criteria (Table 21). 
Table 21. Number of occurrences for each threatened and endangered species ( $E=$ endangered, $\mathrm{T}=$ threatened, and $\mathrm{C}=$ candidate)

\begin{tabular}{|c|l|l|l|c|c|}
\hline $\begin{array}{c}\text { Number of } \\
\text { Occurrences }\end{array}$ & \multicolumn{1}{|c|}{ Scientific Name } & \multicolumn{1}{|c|}{ Common Name } & \multicolumn{1}{c|}{ Category } & $\begin{array}{l}\text { Federal } \\
\text { Status }\end{array}$ & $\begin{array}{l}\text { State } \\
\text { Status }\end{array}$ \\
\hline 12 & Lanius ludovicianus & Loggerhead Shrike & Vertebrate Animal & & $\mathrm{T}$ \\
\hline 6 & Hesperia dacotae & Dakota Skipper & $\begin{array}{l}\text { Invertebrate } \\
\text { Animal }\end{array}$ & $\mathrm{C}$ & $\mathrm{T}$ \\
\hline 6 & $\begin{array}{l}\text { Rhynchospora } \\
\text { capillacea }\end{array}$ & Hair-like Beak-rush & Vascular Plant & & $\mathrm{T}$ \\
\hline 3 & $\begin{array}{l}\text { Actinonaias } \\
\text { ligamentina }\end{array}$ & Mucket & $\begin{array}{l}\text { Invertebrate } \\
\text { Animal }\end{array}$ & & $\mathrm{T}$ \\
\hline 3 & Cyperus acuminatus & $\begin{array}{l}\text { Short-pointed Umbrella- } \\
\text { sedge }\end{array}$ & Vascular Plant & & $\mathrm{T}$ \\
\hline 3 & Phalaropus tricolor & Wilson's Phalarope & Vertebrate Animal & & $\mathrm{T}$ \\
\hline 2 & $\begin{array}{l}\text { Alasmidonta } \\
\text { marginata }\end{array}$ & Elktoe & Invertebrate & & $\mathrm{T}$ \\
\hline 2 & Carex sterilis & Sterile Sedge & Vascular Plant & & $\mathrm{T}$ \\
\hline 2 & Viola nuttallii & Yellow Prairie Violet & Vascular Plant & & $\mathrm{T}$ \\
\hline 1 & Agalinis auriculata & Eared False Foxglove & Vascular Plant & & $\mathrm{E}$ \\
\hline 1 & Buellia nigra & A Species of Lichen & Fungus & & $\mathrm{E}$ \\
\hline 1 & Calcarius ornatus & $\begin{array}{l}\text { Chestnut-collared } \\
\text { Longspur }\end{array}$ & Vertebrate Animal & & $\mathrm{E}$ \\
\hline
\end{tabular}

We then calculated the Euclidian distance from each separate occurrence out to 1 mile. Next, we normalized these scores from 0 to 100, where 100 represented those cells that contained the occurrence point and 0 represented those cells that were at least 1 mile away. Next, we calculated the average of the 12 species scores for each cell. Figure 18 depicts the results of the overlap of the occurrence buffers. 


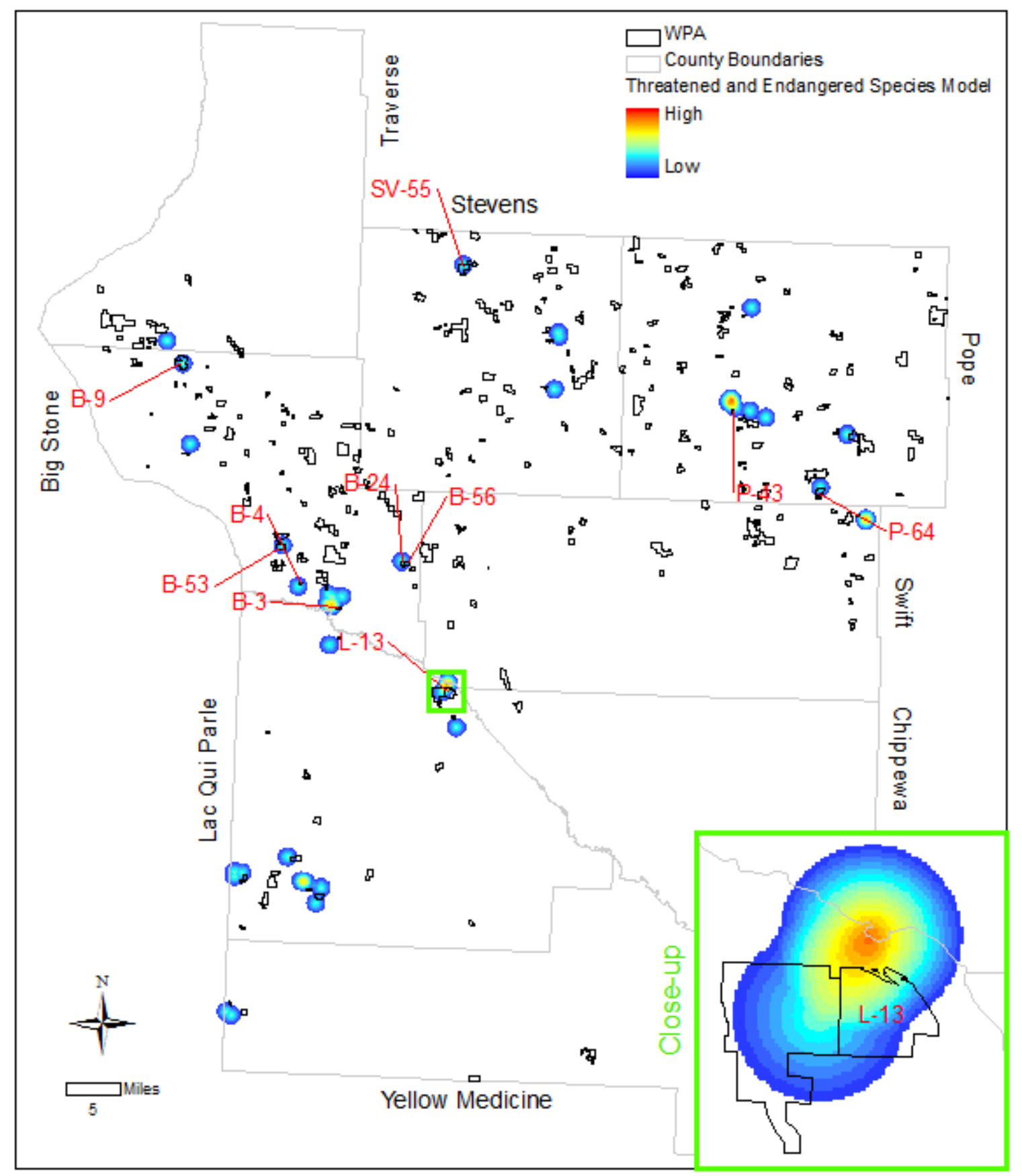

Figure 18. Threatened and endangered species map. WPAs with the top 10 scores for this model are highlighted.

The overlapping cells from this raster were then summarized for each WPA boundary and the mean score is used to determine those WPAs with the highest value (Table 22). This method not only takes into account how many species have buffers that intersect the WPA but also the relative distance that the occurrences are to the WPA. 
Table 22. Top ranked WPAs in terms of mean threatened and endangered species score

\begin{tabular}{|l|l|l|c|c|}
\hline Rank & WPA ID & WPA Name & WPA Size (acres) & Mean T and E Score \\
\hline 1 & P-43 & Glacial Lake & 40.0 & 6.5 \\
\hline 2 & B-24 & Krogsrud & 85.2 & 6.0 \\
\hline 3 & L-13 & Hegland & 463.3 & 5.5 \\
\hline 4 & B-3 & Bucholz & 37.4 & 5.3 \\
\hline 5 & B-4 & Menzel & 20.2 & 4.9 \\
\hline 6 & B-53 & Prairie & 237.5 & 4.8 \\
\hline 7 & SV-55 & Geise & 473.0 & 4.2 \\
\hline 8 & B-56 & Nelson & 116.0 & 4.2 \\
\hline 9 & B-9 & Barry Lake & 630.3 & 3.9 \\
\hline 10 & P-64 & Larson & 297.1 & 3.5 \\
\hline
\end{tabular}

\section{Overall WPA Prioritization Model}

The previous five models each prioritize WPAs based on a single objective of Morris WMD. The individual objective models are useful to help the district understand the value of each WPA for each objective, but realistically the district has the complex task of trying to integrate each of these objectives when making management decisions. To account for this, we created a model to encompass all of the individual objective models. Initially, each component in this overall prioritization model was given equal weighting (Table 23).

Table 23. Overall prioritization model individual objective model weighting breakdown

\begin{tabular}{|l|c|}
\hline Objective Model & Integer Weight \\
\hline Breeding Waterfowl Model & 20 \\
\hline Grassland Birds Model & 20 \\
\hline Tallgrass Prairie Model & 20 \\
\hline Prairie Wetland Ecosystem Model & 20 \\
\hline Threatened and Endangered Species Model & 20 \\
\hline Total & 100 \\
\hline
\end{tabular}

Each of the individual objective models was normalized from 0 to 100 before the overall prioritization model was calculated. Figure 19 depicts the results of the overall prioritization model and Table 24 lists the top 10 ranked WPAs in terms of mean overall prioritization model score. These results are also available online in a sortable format at http://www.umesc.usgs.gov/management/dss/morris wmd/wpa_priority.html 


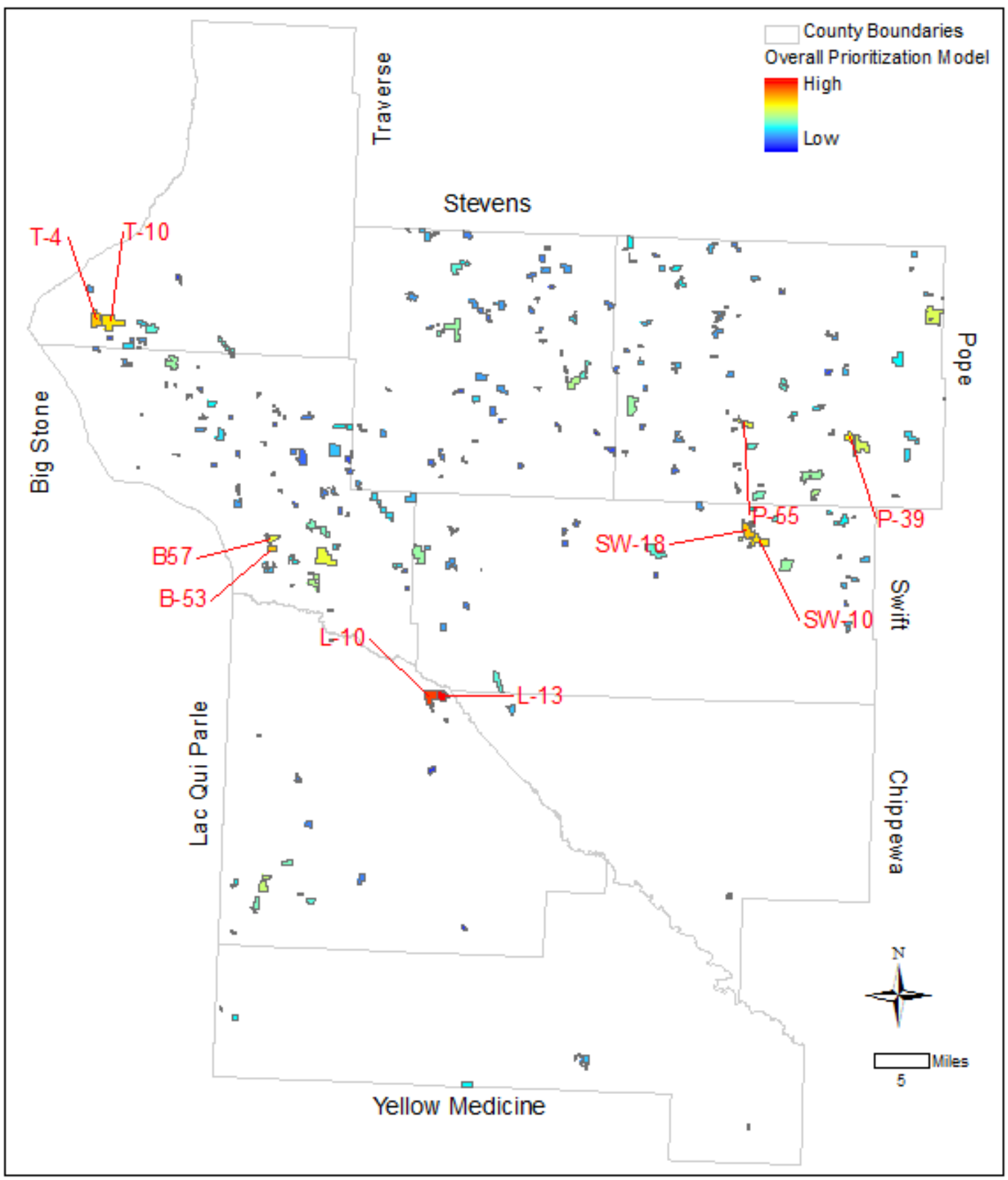

Figure 19. Overall prioritization model results map. WPAs with the top 10 scores for this model are highlighted. 
Table 24. Top ranked WPAs in terms of mean overall prioritization model score. Individual objective model scores are provided for comparison (darker red cells indicate the relative ranking of the WPA for each model).

\begin{tabular}{|c|c|c|c|c|c|c|c|c|c|}
\hline Rank & $\begin{array}{l}\text { WPA } \\
\text { ID }\end{array}$ & $\begin{array}{l}\text { WPA } \\
\text { Name }\end{array}$ & $\begin{array}{l}\text { WPA } \\
\text { Size } \\
\text { (acres) }\end{array}$ & $\begin{array}{l}\text { Mean } \\
\text { Overall } \\
\text { Model } \\
\text { Score }\end{array}$ & $\begin{array}{l}\text { T\&E } \\
\text { Score }\end{array}$ & $\begin{array}{c}\text { Breeding } \\
\text { Water- } \\
\text { fowl } \\
\text { Score }\end{array}$ & $\begin{array}{c}\text { Grass- } \\
\text { land } \\
\text { Birds } \\
\text { Model } \\
\text { Score }\end{array}$ & $\begin{array}{c}\text { Tallgrass } \\
\text { Prairie } \\
\text { Model } \\
\text { Score }\end{array}$ & $\begin{array}{c}\text { Prairie } \\
\text { Wetland } \\
\text { Eco- } \\
\text { system } \\
\text { Model } \\
\text { Score }\end{array}$ \\
\hline 1 & L-13 & Hegland & 463.3 & 90.8 & 84.8 & 95.7 & 90.8 & 84.9 & 97.9 \\
\hline 2 & L-10 & Hastad & 947.2 & 86.8 & 48.9 & 98.2 & 100.0 & 100.0 & 87.0 \\
\hline 3 & B-53 & Prairie & 237.5 & 68.2 & 74.8 & 86.1 & 70.2 & 40.3 & 69.4 \\
\hline 4 & $\mathrm{~T}-4$ & $\begin{array}{l}\text { Mosquito } \\
\text { Ranch }\end{array}$ & 753.0 & 67.8 & 0.00 & 100.0 & 79.3 & 59.8 & 100.0 \\
\hline 5 & $\begin{array}{l}\text { SW- } \\
18\end{array}$ & Loen & 879.4 & 66.6 & 0.00 & 92.8 & 88.1 & 65.6 & 86.3 \\
\hline 6 & $\begin{array}{l}\text { SW- } \\
10\end{array}$ & Svor & 706.4 & 65.7 & 0.00 & 91.5 & 83.6 & 65.5 & 88.1 \\
\hline 7 & $\mathrm{~T}-10$ & $\begin{array}{l}\text { Robin } \\
\text { Hood }\end{array}$ & 1250.9 & 64.7 & 0.00 & 87.4 & 70.1 & 66.9 & 99.3 \\
\hline 8 & P-39 & Overby & 313.8 & 62.2 & 41.8 & 74.6 & 50.5 & 54.8 & 89.3 \\
\hline 9 & B-57 & $\begin{array}{l}\text { Twin } \\
\text { Lakes }\end{array}$ & 404.6 & 57.7 & 10.2 & 83.2 & 79.0 & 53.3 & 63.0 \\
\hline 10 & P-55 & $\begin{array}{l}\text { Blue } \\
\text { Mounds }\end{array}$ & 392.8 & 56.6 & 0.6 & 88.9 & 70.1 & 46.6 & 77.0 \\
\hline
\end{tabular}

\section{Custom Weighting Tools}

\section{Overall WPA Prioritization Model Custom Weighting Tool}

The results displayed in the overall prioritization model section were based upon a weighting scheme where all five separate components to the overall model were given an equal weighting of 20. In many decision making situations, however, managers may want to adjust the model to place more emphasis on a certain station objective. For example, the primary purpose of a wetland management district is waterfowl production, so perhaps the breeding waterfowl model should have a higher weight than the other four objective models. The manager could look only at the breeding waterfowl model to assess which WPAs have the most potential for waterfowl production, but by adjusting the weight of that component in the overall model, they can still take the other station objectives into account.

An interactive database tool was developed using Microsoft Access and Visual Basic for Applications to allow the user to accomplish this. When the Access database is opened a form 
appears and prompts the user to input model weighting scores for each of the five objective models (Figure 20). The sum of all weights input must equal 100. The user then enters a name for the output table generated and is also asked to specify if the created tables should be exported as Microsoft Excel tables. When the user clicks the button "Create Model Scores," a table is populated on the form with all WPAs listed in order from highest overall model score to lowest.

For example, Table 25 shows a customized weighting system recommended by Morris WMD staff, which reflects the weights they would realistically give to their station objectives. The custom weighting tool was used to create overall model scores for WPAs using these two sets of model weights. The top 15 WPAs for each weighting system are listed in Table 26 . While the top 15 WPAs are almost the same for the two lists, they are prioritized differently. The two lists start to prioritize WPAs even more differently beyond the top 20 WPAs.

The Overall WPA Prioritization Model Custom Weighting Tool is available online at: http://www.umesc.usgs.gov/management/dss/morris wmd.html

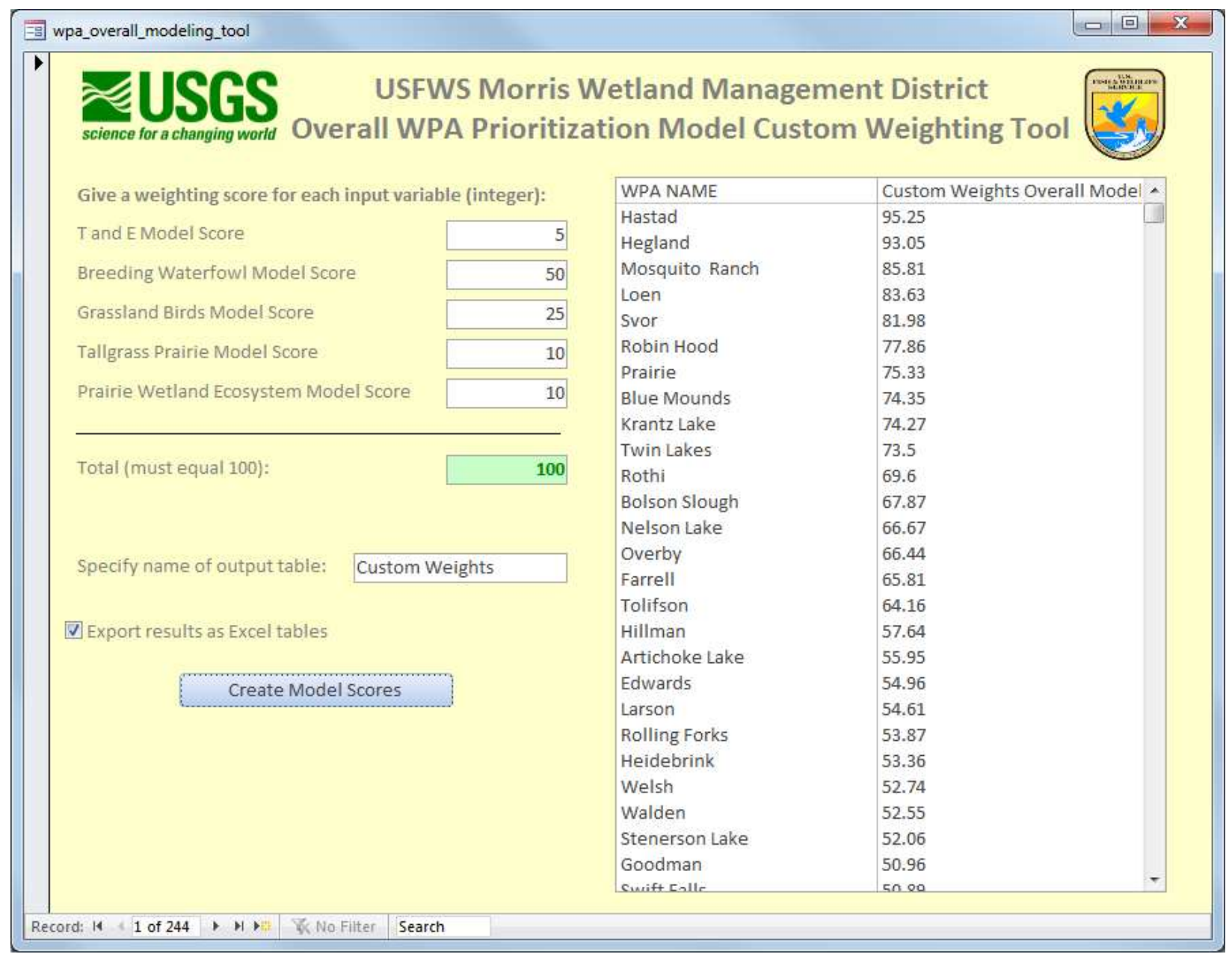

Figure 20. Dialog window for the Overall WPA Prioritization Model Custom Weighting Tool 
Table 25. Comparison of even and customized weights for Overall WPA Prioritization Model

\begin{tabular}{|l|c|c|}
\hline Objective Model & Even Weights & Custom Weights \\
\hline Breeding Waterfowl Model & 20 & 50 \\
\hline Grassland Birds Model & 20 & 25 \\
\hline Tallgrass Prairie Model & 20 & 10 \\
\hline Prairie Wetland Ecosystem Model & 20 & 10 \\
\hline Threatened and Endangered Species Model & 20 & 5 \\
\hline Total & 100 & 100 \\
\hline
\end{tabular}

Table 26. Top ranked WPAs under two different model weight scenarios

\begin{tabular}{|l|l|c|c|c|c|}
\hline \multirow{2}{*}{ WPA ID } & \multirow{2}{*}{ WPA Name } & \multicolumn{2}{|c|}{ Even Weights } & \multicolumn{2}{l|}{ Custom Weights } \\
\cline { 3 - 6 } & & Score & Rank & Score & Rank \\
\hline L-10 & Hastad & 86.8 & 2 & 95.3 & 1 \\
\hline L-13 & Hegland & 90.8 & 1 & 93.1 & 2 \\
\hline T-4 & Mosquito Ranch & 67.8 & 4 & 85.8 & 3 \\
\hline SW-18 & Loen & 66.6 & 5 & 83.6 & 4 \\
\hline SW-10 & Svor & 65.7 & 6 & 82.0 & 5 \\
\hline T-10 & Robin Hood & 64.7 & 7 & 77.9 & 6 \\
\hline B-53 & Prairie & 68.2 & 3 & 75.3 & 7 \\
\hline P-55 & Blue Mounds & 56.6 & 10 & 74.4 & 8 \\
\hline P-32 & Krantz Lake & 56.0 & 12 & 74.3 & 9 \\
\hline B-57 & Twin Lakes & 57.7 & 9 & 73.5 & 10 \\
\hline B-2 & Rothi & 56.3 & 11 & 69.6 & 11 \\
\hline L-6 & Bolson Slough & 49.5 & 16 & 67.9 & 12 \\
\hline P-38 & Nelson Lake & 55.3 & 13 & 66.7 & 13 \\
\hline P-39 & Overby & 62.2 & 8 & 66.4 & 14 \\
\hline L-5 & Farrell & 50.9 & 15 & 65.8 & 15 \\
\hline SW-25 & Tolifson & 52.3 & 14 & 64.2 & 16 \\
\hline
\end{tabular}

\section{Objective Model Custom Weighting Tool}

Another Microsoft Access database tool was developed to allow the user to explore the criteria weighting system for the objective models. This would be valuable if the user wanted to develop a model for a station objective not covered by one of the current objective models (breeding waterfowl, grassland birds, tallgrass prairie, prairie wetlands, and threatened and endangered species) or if the user does not agree with the current weighting of an objective model and wants to use their own input criteria weights. This custom tool can be used to rerun those objective models. 
When the Access database is opened a form appears and prompts the user to input variable weighting scores for each of the eleven separate variable components. The sum of all weights input must equal 100. The user then enters a name for the output table generated and is also asked to specify if the tables developed should be exported as Microsoft Excel tables. When the user clicks the button "Create Model Scores", a table is populated on the form with all WPAs listed and in order from highest objective model score to lowest (Figure 21).

The Objective Model Custom Weighting Tool is available online at: http://www.umesc.usgs.gov/management/dss/morris wmd.html

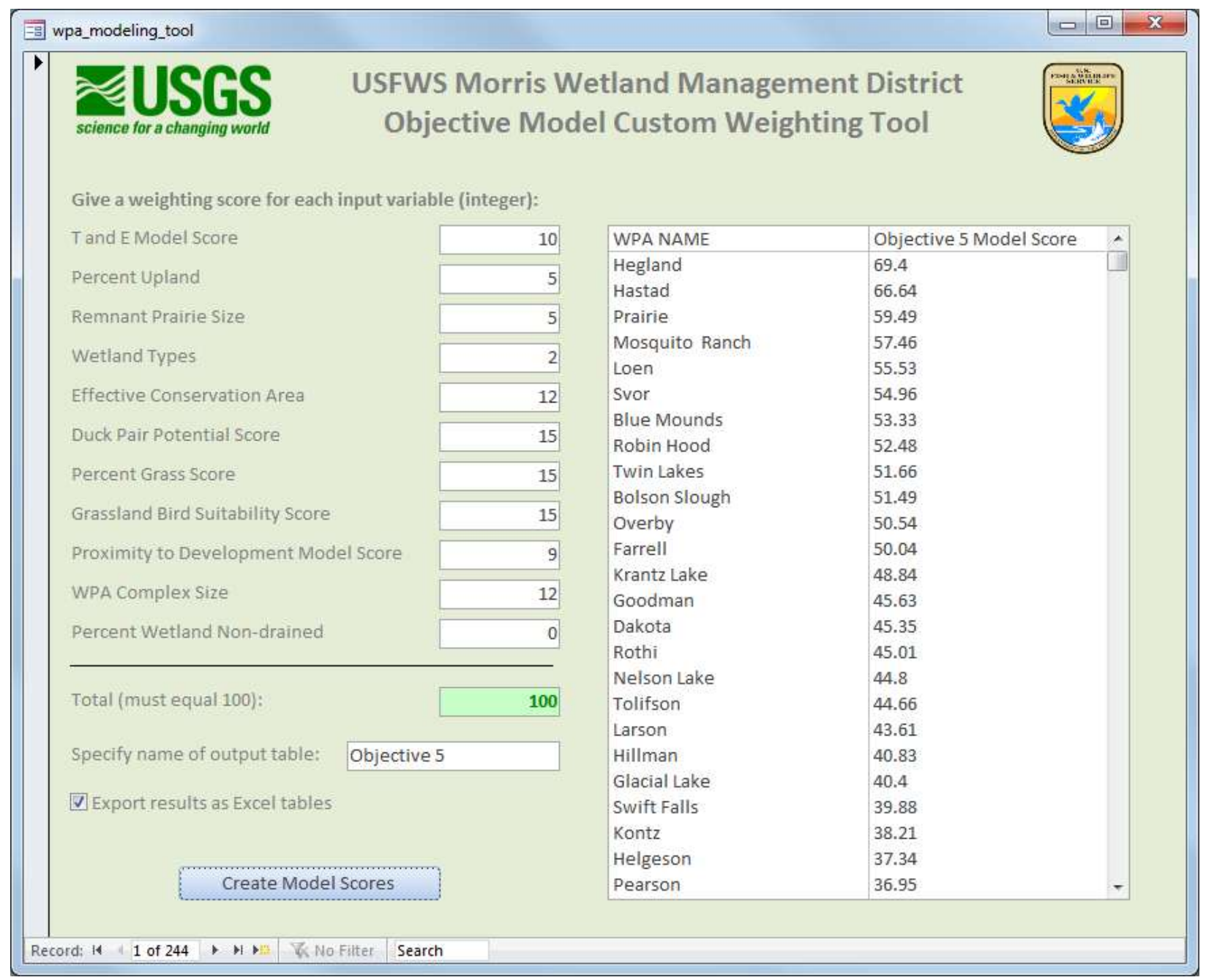

Figure 21. Dialog window for the Objective Model Custom Weighting Tool

\section{Summary}

Morris WMD is already using this decision support tool to make thoughtful and strategic choices about where to spend its limited management resources. The staff values the output of this tool because they were involved in its development and contributed to the criteria used to build it. Past management decisions made at Morris WMD have incorporated these objectives 
and criteria, so in many cases the top ranked WPAs were not a surprise. However, the tool makes that "mental model" more transparent, improving the defensibility of management decisions. Importantly, there were some top ranked WPAs that had previously been unmanaged or undermanaged, and these parcels will now deservedly receive increased attention.

\section{References Cited}

Cowardin, L. M., V. Carter, F. C. Golet, and E. T. LaRoe. 1979. Classification of wetlands and deepwater habitats of the United States. U.S. Fish and Wildlife Service, FWS/OBS-79/31.

Johnson, R. R., F. T. Oslund, and D. R. Hertel. 2008. The past, present, and future of prairie potholes in the United States. Journal of Soil and Water Conservation 63(3):84a-87a.

Minnesota Department of Natural Resources, [n.d], Natural Heritage Information System, accessed February 8, 2011, at URL http://www.dnr.state.mn.us/eco/nhnrp/nhis.html

Quamen, F. R. 2007. A landscape approach to grassland bird conservation in the prairie pothole region of the northern great plains. Dissertation, University of Montana, Missoula

Samson, F. and F. Knopf. 1994. Prairie conservation in North America. BioScience 44(6):418421.

Sauer, J. R., J. E. Hines, and J. Fallon. 2008. The North American Breeding Bird Survey, Results and Analysis 1966 - 2007. Version 5.15.2008. USGS Patuxent Wildlife Research Center, Laurel, MD. Accessed February 23, 2011, at URL http://www.mbr-pwrc.usgs.gov/bbs/

Shaw, S. P. and C. G. Fredine. 1959. Wetlands of the United States: Their extent and their value to waterfowl and other wildlife. Circular 39, U.S. Fish and Wildlife Service.

U.S. Fish and Wildlife Service, [n.d.a], Habitat and Population Evaluation Team, Predicted Duck Pair Accesssibility Maps (Thunderstorm Maps), accessed February 8, 2011, at URL http://www.fws.gov/midwest/hapet/ThunderStormMaps.html

U.S. Fish and Wildlife Service, [n.d.b], Habitat and Population Evaluation Team, Land Cover Maps, accessed February 8, 2011, at URL http://www.fws.gov/midwest/hapet/LandCoverMaps.html

U.S. Fish and Wildlife Service, [n.d.c], Habitat and Population Evaluation Team, A Landscape Approach to Grassland Bird Conservation, accessed February 8, 2011, at URL http://www.fws.gov/midwest/hapet/LandscapeGrasslandBirds.html 
Appendix 1. List of attendees at original Morris Wetland Management District prioritization workshop

\begin{tabular}{|l|l|}
\hline Bruce Freske & USFWS Morris Wetland Management District \\
\hline Frank Durbian & USFWS Morris Wetland Management District \\
\hline Sara Vacek & USFWS Morris Wetland Management District \\
\hline Stacy Salvevold & USFWS Morris Wetland Management District \\
\hline Styron Bell & USFWS Morris Wetland Management District \\
\hline JB Bright & USFWS Morris Wetland Management District \\
\hline Derrick Odegard & USFWS Morris Wetland Management District \\
\hline Donna Oglesby & USFWS Morris Wetland Management District \\
\hline Karen Stettner & USFWS Morris Wetland Management District \\
\hline Rodney Ahrndt & USFWS Morris Wetland Management District \\
\hline Joel Boutain & USFWS Morris Wetland Management District \\
\hline Seth Grimm & USFWS Morris Wetland Management District (by phone) \\
\hline Pat Heglund & USFWS Regional Refuge Biologist (by phone) \\
\hline Soch Lor (Facilitator) & USFWS Assistant Regional Biologist/Biological Monitoring Team \\
\hline Josh Eash & USFWS Regional Hydrologist \\
\hline Curt Vacek & Minnesota Department of Natural Resources \\
\hline Dave Trauba & Minnesota Department of Natural Resources \\
\hline Kevin Kotts & Minnesota Department of Natural Resources \\
\hline Diane Granfors & USFWS Habitat and Population Evaluation Team \\
\hline Dan Hertel & USFWS Habitat and Population Evaluation Team \\
\hline
\end{tabular}


Appendix 2. Full list of WPAs, ranked in order from most important to least important relative to the Overall WPA Prioritization Model.

\begin{tabular}{|c|c|c|c|c|c|c|c|}
\hline $\begin{array}{c}\text { WPA } \\
\text { ID }\end{array}$ & WPA NAME & $\begin{array}{c}\text { Overall } \\
\text { Model } \\
\text { Score }\end{array}$ & $\begin{array}{c}\text { T and E } \\
\text { Model } \\
\text { Score }\end{array}$ & $\begin{array}{c}\text { Breeding } \\
\text { Waterfo } \\
\text { wl Model } \\
\text { Score }\end{array}$ & $\begin{array}{c}\text { Grassland } \\
\text { Birds } \\
\text { Model } \\
\text { Score }\end{array}$ & $\begin{array}{c}\text { Tallgrass } \\
\text { Prairie } \\
\text { Model } \\
\text { Score }\end{array}$ & $\begin{array}{c}\text { Prairie } \\
\text { Wetland } \\
\text { Ecosyste } \\
\text { m Model } \\
\text { Score }\end{array}$ \\
\hline $\mathrm{L}-13$ & Hegland & 90.81 & 84.78 & 95.69 & 90.76 & 84.89 & 97.91 \\
\hline $\mathrm{L}-10$ & Hastad & 86.82 & 48.91 & 98.22 & 100 & 100 & 86.99 \\
\hline B-53 & Prairie & 68.18 & 74.84 & 86.13 & 70.21 & 40.29 & 69.42 \\
\hline $\mathrm{T}-4$ & Mosquito Ranch & 67.82 & 0 & 100 & 79.33 & 59.77 & 100 \\
\hline $\begin{array}{l}\text { SW- } \\
18 \\
\end{array}$ & Loen & 66.55 & 0 & 92.84 & 88.09 & 65.55 & 86.28 \\
\hline $\begin{array}{l}\text { SW- } \\
10\end{array}$ & Svor & 65.72 & 0 & 91.46 & 83.56 & 65.45 & 88.14 \\
\hline $\mathrm{T}-10$ & Robin Hood & 64.74 & 0 & 87.43 & 70.11 & 66.86 & 99.3 \\
\hline P-39 & Overby & 62.21 & 41.77 & 74.62 & 50.52 & 54.82 & 89.3 \\
\hline B-57 & Twin Lakes & 57.74 & 10.24 & 83.23 & 78.98 & 53.25 & 62.98 \\
\hline$P-55$ & Blue Mounds & 56.64 & 0.62 & 88.86 & 70.09 & 46.62 & 77.03 \\
\hline$B-2$ & Rothi & 56.3 & 0 & 80.64 & 61.32 & 52.3 & 87.23 \\
\hline P-32 & Krantz Lake & 55.99 & 0 & 89.63 & 69.51 & 51.73 & 69.07 \\
\hline $\mathrm{P}-38$ & Nelson Lake & 55.3 & 0 & 75.77 & 58.07 & 54.5 & 88.14 \\
\hline $\begin{array}{l}\text { SW- } \\
25 \\
\end{array}$ & Tolifson & 52.33 & 0 & 71.02 & 63.94 & 54.65 & 72.04 \\
\hline$L-5$ & Farrell & 50.88 & 0 & 76.38 & 65.47 & 36.32 & 76.24 \\
\hline $\mathrm{L}-6$ & Bolson Slough & 49.47 & 0 & 81.84 & 69.29 & 38.03 & 58.21 \\
\hline P-64 & Larson & 48.1 & 54.34 & 66.33 & 44.98 & 17.19 & 57.65 \\
\hline B-14 & Hillman & 46.68 & 1.55 & 65.77 & 53.83 & 43.62 & 68.62 \\
\hline SV-16 & Edwards & 46.22 & 0 & 58.18 & 57.19 & 36.56 & 79.18 \\
\hline $\begin{array}{l}\text { SW- } \\
21 \\
\end{array}$ & Artichoke Lake & 44.5 & 0 & 63.43 & 55.48 & 30.25 & 73.36 \\
\hline SW-4 & Welsh & 43.88 & 0 & 59.31 & 47.16 & 43.34 & 69.61 \\
\hline $\mathrm{P}-17$ & Heidebrink & 43.02 & 0 & 62.31 & 46.19 & 31.51 & 75.07 \\
\hline P-19 & Walden & 42.98 & 0 & 58.8 & 50.29 & 29.99 & 75.83 \\
\hline$B-9$ & Barry Lake & 42.14 & 60.4 & 39.02 & 20.62 & 19.91 & 70.76 \\
\hline SV-45 & Pepperton & 42.13 & 0 & 60.47 & 34.23 & 33.76 & 82.21 \\
\hline $\mathrm{P}-43$ & Glacial Lake & 42.05 & 100 & 37.35 & 36.81 & 12.16 & 23.94 \\
\hline B-12 & Kufrin WPA & 41.15 & 0 & 58.05 & 39.39 & 33.67 & 74.63 \\
\hline $\mathrm{L}-12$ & Goodman & 40.86 & 24.99 & 60.14 & 51.51 & 26.36 & 41.28 \\
\hline SV-3 & Freeman & 40.68 & 0 & 59.12 & 41.25 & 31.67 & 71.37 \\
\hline P-10 & Rolling Forks & 40.31 & 0 & 65.85 & 49.19 & 23.52 & 62.98 \\
\hline $\mathrm{L}-7$ & Pearson & 39.89 & 0 & 57.64 & 45.76 & 34.54 & 61.51 \\
\hline
\end{tabular}




\begin{tabular}{|c|c|c|c|c|c|c|c|}
\hline $\begin{array}{c}\text { WPA } \\
\text { ID }\end{array}$ & WPA NAME & $\begin{array}{c}\text { Overall } \\
\text { Model } \\
\text { Score }\end{array}$ & $\begin{array}{c}\text { T and E } \\
\text { Model } \\
\text { Score }\end{array}$ & $\begin{array}{c}\text { Breeding } \\
\text { Waterfo } \\
\text { wl Model } \\
\text { Score }\end{array}$ & $\begin{array}{c}\text { Grassland } \\
\text { Birds } \\
\text { Model } \\
\text { Score }\end{array}$ & $\begin{array}{c}\text { Tallgrass } \\
\text { Prairie } \\
\text { Model } \\
\text { Score }\end{array}$ & $\begin{array}{l}\text { Prairie } \\
\text { Wetland } \\
\text { Ecosyste } \\
\text { m Model } \\
\text { Score }\end{array}$ \\
\hline $\mathrm{T}-2$ & Lawrence & 38.3 & 0.62 & 60.19 & 48.86 & 21.88 & 59.93 \\
\hline SV-55 & Geise & 37.83 & 64.74 & 40.64 & 27.71 & 18.39 & 37.67 \\
\hline $\begin{array}{l}\text { SW- } \\
16\end{array}$ & Lynch Lake & 37.4 & 0 & 50.68 & 39.92 & 31.96 & 64.43 \\
\hline L-16 & Florida Creek & 37.38 & 47.05 & 48.9 & 40.08 & 22.16 & 28.72 \\
\hline P-42 & Stenerson Lake & 37.07 & 0 & 67.22 & 44.28 & 13.49 & 60.34 \\
\hline SV-2 & Long Lake & 36.86 & 0 & 47.08 & 45.18 & 33.23 & 58.82 \\
\hline $\begin{array}{l}\text { SW- } \\
15\end{array}$ & Appleton & 36.78 & 0 & 46.74 & 42.58 & 34.13 & 60.43 \\
\hline $\begin{array}{l}\text { SW- } \\
14\end{array}$ & Swift Falls & 35.95 & 0 & 62.54 & 52.65 & 18.87 & 45.69 \\
\hline P-8 & Kolstad Lake & 35.63 & 0 & 65.47 & 44.29 & 17.4 & 50.99 \\
\hline $\mathrm{T}-1$ & Geyer & 35.5 & 0 & 57.1 & 40.8 & 15.75 & 63.87 \\
\hline B-24 & Krogsrud & 35.45 & 93.63 & 21.9 & 6.03 & 7.65 & 48.04 \\
\hline$L-1$ & Borass & 35.25 & 2.01 & 44.64 & 39.22 & 38.38 & 52 \\
\hline YM-4 & Dakota & 35.09 & 0.15 & 58.04 & 43.39 & 27.3 & 46.55 \\
\hline SW-8 & Big Slough & 35.01 & 0 & 53.95 & 43.16 & 22.59 & 55.34 \\
\hline$P-46$ & Grove Lake & 34.86 & 0 & 57.3 & 52.52 & 25.01 & 39.48 \\
\hline$P-52$ & Hagstrom & 34.51 & 0 & 57.31 & 42.24 & 16.45 & 56.55 \\
\hline B-30 & Seidl & 34.41 & 0 & 61 & 39.2 & 14.93 & 56.93 \\
\hline $\mathrm{L}-18$ & Freeland & 34.29 & 32.29 & 48.13 & 35.87 & 19.88 & 35.27 \\
\hline B-51 & Odden & 33.73 & 0 & 51.84 & 39.2 & 14.81 & 62.78 \\
\hline $\mathrm{P}-2$ & Mciver & 33.4 & 0 & 55.49 & 39.73 & 11.9 & 59.9 \\
\hline SV-20 & Kill & 33.06 & 30.9 & 33.05 & 16.79 & 19.1 & 65.46 \\
\hline $\mathrm{P}-12$ & Stenson Lake & 32.79 & 0 & 56.22 & 31.54 & 16.09 & 60.09 \\
\hline$B-3$ & Bucholz & 32.47 & 83.23 & 25.42 & 16.75 & 13.06 & 23.91 \\
\hline$L-8$ & Taylor & 32.26 & 50.46 & 29.73 & 22.43 & 18.9 & 39.76 \\
\hline $\mathrm{P}-40$ & Rosby Lake & 32.24 & 0 & 56.02 & 37.65 & 9.16 & 58.36 \\
\hline B-15 & Helgeson & 32.09 & 0 & 57.28 & 38.52 & 19.72 & 44.95 \\
\hline $\begin{array}{l}\text { SW- } \\
19\end{array}$ & Fahl & 31.89 & 0 & 55.34 & 43.75 & 14.7 & 45.67 \\
\hline YM-5 & Swede Home & 31.79 & 0 & 48.77 & 44.57 & 13.33 & 52.29 \\
\hline $\mathrm{P}-18$ & Wall & 31.3 & 0 & 54.35 & 28.7 & 20.25 & 53.19 \\
\hline B-1 & Karsky & 31.1 & 0 & 54.14 & 36.22 & 12.11 & 53.02 \\
\hline $\mathrm{P}-20$ & Paulson & 30.65 & 0 & 59.77 & 35.89 & 13.13 & 44.48 \\
\hline B-56 & Nelson & 30.4 & 64.74 & 26.33 & 14.49 & 8.09 & 38.36 \\
\hline $\begin{array}{l}\text { SW- } \\
26\end{array}$ & Hanson & 30.37 & 0 & 56.42 & 40.09 & 11.56 & 43.79 \\
\hline
\end{tabular}




\begin{tabular}{|c|c|c|c|c|c|c|c|}
\hline $\begin{array}{l}\text { WPA } \\
\text { ID }\end{array}$ & WPA NAME & $\begin{array}{c}\text { Overall } \\
\text { Model } \\
\text { Score }\end{array}$ & $\begin{array}{c}\text { T and E } \\
\text { Model } \\
\text { Score }\end{array}$ & $\begin{array}{c}\text { Breeding } \\
\text { Waterfo } \\
\text { wl Model } \\
\text { Score }\end{array}$ & $\begin{array}{c}\text { Grassland } \\
\text { Birds } \\
\text { Model } \\
\text { Score }\end{array}$ & $\begin{array}{c}\text { Tallgrass } \\
\text { Prairie } \\
\text { Model } \\
\text { Score }\end{array}$ & $\begin{array}{l}\text { Prairie } \\
\text { Wetland } \\
\text { Ecosyste } \\
\text { m Model } \\
\text { Score }\end{array}$ \\
\hline P-59 & Johnson (Pope) & 30.2 & 0 & 49.51 & 37.74 & 13.64 & 50.12 \\
\hline$T-3$ & Paul & 29.71 & 0 & 46.36 & 36.56 & 22.5 & 43.13 \\
\hline $\mathrm{T}-12$ & Diekmann & 29.57 & 0 & 54.38 & 31.32 & 12.73 & 49.42 \\
\hline$P-50$ & Benson Lake & 29.32 & 0 & 53.61 & 38.57 & 8.49 & 45.95 \\
\hline$P-51$ & Hanson & 29.28 & 0 & 53.49 & 36.53 & 3.38 & 52.98 \\
\hline SV-8 & Thorstad & 29.19 & 0 & 50.37 & 32.65 & 6.28 & 56.67 \\
\hline B-6 & Henry & 28.9 & 0 & 51.26 & 35.69 & 11.23 & 46.33 \\
\hline B-4 & Menzel & 28.87 & 76.09 & 20.44 & 18.14 & 6.33 & 23.36 \\
\hline B-26 & Artichoke & 28.73 & 0 & 39.31 & 35.08 & 25.45 & 43.79 \\
\hline SV-13 & Lamprecht & 28.4 & 0 & 47.48 & 36.96 & 8.32 & 49.25 \\
\hline $\mathrm{P}-28$ & Lake Johanna & 28.27 & 0 & 36.64 & 23.84 & 18.55 & 62.31 \\
\hline $\mathrm{P}-27$ & Bangor & 28.26 & 0 & 35.79 & 22.67 & 19.42 & 63.41 \\
\hline $\mathrm{P}-36$ & New Prairie & 28.09 & 0 & 45.09 & 37.25 & 10.54 & 47.58 \\
\hline B-20 & Redhead Marsh & 27.96 & 0 & 38.02 & 25.61 & 14.67 & 61.52 \\
\hline SV-22 & $\begin{array}{l}\text { Johnson } \\
\text { (Stevens) }\end{array}$ & 27.87 & 0 & 44.68 & 35.27 & 14.24 & 45.15 \\
\hline $\begin{array}{l}\text { SW- } \\
28\end{array}$ & Monson Lake & 27.51 & 0 & 48.9 & 34.25 & 7.3 & 47.11 \\
\hline $\begin{array}{l}\text { SW- } \\
13\end{array}$ & Bengtson & 27.34 & 0 & 40.35 & 36.16 & 11.38 & 48.83 \\
\hline $\mathrm{C}-1$ & Lundgren & 27.33 & 0 & 36.86 & 30.1 & 22.11 & 47.6 \\
\hline B-32 & Olson & 27.23 & 0 & 37.05 & 34.23 & 12.81 & 52.07 \\
\hline B-21 & Dismal Swamp & 27.18 & 0 & 32.46 & 26.03 & 20.5 & 56.91 \\
\hline $\begin{array}{l}\text { SW- } \\
17\end{array}$ & Brady & 27.14 & 0 & 40.05 & 25.51 & 15.75 & 54.39 \\
\hline B-16 & Beck & 27.02 & 0 & 49.19 & 26.78 & 13.55 & 45.57 \\
\hline $\mathrm{P}-35$ & Ouren & 26.94 & 0.77 & 44.91 & 26.13 & 16.3 & 46.59 \\
\hline $\begin{array}{l}\text { SW- } \\
29\end{array}$ & Roderick & 26.63 & 0 & 47.43 & 40.46 & 7.81 & 37.43 \\
\hline$P-63$ & Hassel Creek & 26.54 & 0 & 50.49 & 38.23 & 9.86 & 34.1 \\
\hline$P-6$ & Staack & 26.48 & 0 & 48.87 & 32.04 & 8.23 & 43.27 \\
\hline B-29 & Daly & 26.46 & 0 & 45.16 & 37.51 & 13.86 & 35.77 \\
\hline P-13 & Berg & 26.4 & 0 & 51.32 & 33.72 & 12.6 & 34.35 \\
\hline $\mathrm{L}-17$ & Plover & 26.09 & 0 & 50.72 & 31.92 & 14.42 & 33.4 \\
\hline$P-21$ & Moen & 26.08 & 0 & 43.2 & 24.36 & 6.34 & 56.52 \\
\hline$P-61$ & Westport & 26.04 & 0 & 42.89 & 29.77 & 11.33 & 46.22 \\
\hline$P-3$ & $\begin{array}{l}\text { Little Chippewa } \\
\text { River }\end{array}$ & 25.83 & 0 & 39.53 & 28.9 & 12.29 & 48.41 \\
\hline
\end{tabular}




\begin{tabular}{|c|c|c|c|c|c|c|c|}
\hline $\begin{array}{l}\text { WPA } \\
\text { ID }\end{array}$ & WPA NAME & $\begin{array}{c}\text { Overall } \\
\text { Model } \\
\text { Score }\end{array}$ & $\begin{array}{c}\text { T and E } \\
\text { Model } \\
\text { Score }\end{array}$ & $\begin{array}{c}\text { Breeding } \\
\text { Waterfo } \\
\text { wl Model } \\
\text { Score }\end{array}$ & $\begin{array}{c}\text { Grassland } \\
\text { Birds } \\
\text { Model } \\
\text { Score }\end{array}$ & $\begin{array}{c}\text { Tallgrass } \\
\text { Prairie } \\
\text { Model } \\
\text { Score } \\
\end{array}$ & $\begin{array}{c}\text { Prairie } \\
\text { Wetland } \\
\text { Ecosyste } \\
\text { m Model } \\
\text { Score }\end{array}$ \\
\hline YM-1 & Kontz & 25.7 & 10.09 & 38.94 & 31.22 & 15.03 & 33.22 \\
\hline P-5 & Gjerdingen & 25.28 & 0 & 48.76 & 35.92 & 7.42 & 34.32 \\
\hline YM-3 & Spellman Lake & 25.15 & 0 & 32.28 & 35.41 & 14.15 & 43.93 \\
\hline $\begin{array}{l}\text { SW- } \\
23\end{array}$ & Gilbertson & 25.14 & 0 & 42.61 & 39.23 & 7.84 & 36.01 \\
\hline P-29 & Ben Wade & 25.14 & 0 & 34.63 & 19.03 & 11.12 & 60.91 \\
\hline$P-58$ & Glenwood & 25.09 & 0 & 41.97 & 23.48 & 11.99 & 48 \\
\hline $\begin{array}{l}\text { SW- } \\
30\end{array}$ & Loose & 24.99 & 0 & 43.51 & 39.92 & 6.7 & 34.81 \\
\hline P-16 & Klevenberg & 24.95 & 0 & 42.81 & 25.84 & 7.84 & 48.24 \\
\hline$P-54$ & Horse Lake & 24.89 & 0 & 39.81 & 18.1 & 10 & 56.56 \\
\hline $\mathrm{P}-11$ & Bredberg & 24.8 & 0 & 40.79 & 31.25 & 6.61 & 45.33 \\
\hline SV-18 & $\begin{array}{l}\text { Pomme de Terre } \\
\text { River }\end{array}$ & 24.61 & 0 & 35.54 & 23.15 & 17.87 & 46.47 \\
\hline B-8 & Boehnke & 24.55 & 0 & 45.09 & 24.27 & 6.32 & 47.05 \\
\hline P-14 & Stewart & 24.45 & 0 & 41.99 & 25.28 & 12.18 & 42.82 \\
\hline SV-53 & Mud Creek & 24.41 & 0 & 28.43 & 19.48 & 18.37 & 55.75 \\
\hline SV-17 & Grossman & 24.18 & 0 & 42.63 & 39.14 & 4.43 & 34.68 \\
\hline B-50 & Tangen & 24.15 & 0 & 32.28 & 20.45 & 16.2 & 51.84 \\
\hline B-52 & Anderson & 24.08 & 0 & 36.48 & 18.61 & 8.74 & 56.55 \\
\hline $\mathrm{P}-26$ & Greiner & 23.25 & 0 & 31.33 & 29.99 & 13.08 & 41.85 \\
\hline SV-38 & Fish Lake & 23.02 & 0 & 29.81 & 21.16 & 11.11 & 53.02 \\
\hline SV-19 & Smith & 23.01 & 0 & 37.54 & 19.35 & 12.18 & 45.97 \\
\hline SW-1 & Lubenow & 22.89 & 0 & 26.33 & 18.47 & 20.04 & 49.61 \\
\hline SV-5 & Wente & 22.87 & 0 & 32.34 & 15.01 & 11.1 & 55.88 \\
\hline SV-23 & Schultz & 22.71 & 0 & 31.94 & 14.7 & 11.28 & 55.61 \\
\hline $\begin{array}{l}\text { SW- } \\
24\end{array}$ & Spring Lake & 22.68 & 0 & 29.24 & 28.74 & 8.19 & 47.22 \\
\hline SV-21 & Fults & 22.47 & 0 & 32.8 & 22.11 & 9.52 & 47.91 \\
\hline $\mathrm{P}-41$ & Stammer & 22.47 & 0 & 37.23 & 21.96 & 6.29 & 46.86 \\
\hline SV-7 & Stevens & 22.42 & 0 & 32.5 & 30.24 & 3.94 & 45.4 \\
\hline $\mathrm{T}-8$ & Parnell & 22.37 & 0 & 45.88 & 27.59 & 4.74 & 33.64 \\
\hline SV-29 & Mcnally Slough & 22.3 & 0 & 30.15 & 25.02 & 7.42 & 48.93 \\
\hline B-23 & Stegner & 22.22 & 0 & 38.23 & 22.94 & 10.14 & 39.77 \\
\hline $\mathrm{C}-2$ & Hawk Creek & 22.14 & 0 & 30.93 & 26.15 & 6.26 & 47.35 \\
\hline P-62 & Scofield & 22.08 & 0 & 29.49 & 18.8 & 12.77 & 49.34 \\
\hline T-9 & Murphy & 22.03 & 0 & 43.44 & 29.19 & 9.04 & 28.47 \\
\hline $\mathrm{T}-11$ & Pedersen & 21.97 & 0 & 37.96 & 21.56 & 4.69 & 45.62 \\
\hline
\end{tabular}




\begin{tabular}{|c|c|c|c|c|c|c|c|}
\hline $\begin{array}{c}\text { WPA } \\
\text { ID }\end{array}$ & WPA NAME & $\begin{array}{c}\text { Overall } \\
\text { Model } \\
\text { Score }\end{array}$ & $\begin{array}{c}\text { T and E } \\
\text { Model } \\
\text { Score }\end{array}$ & $\begin{array}{c}\text { Breeding } \\
\text { Waterfo } \\
\text { wl Model } \\
\text { Score }\end{array}$ & $\begin{array}{c}\text { Grassland } \\
\text { Birds } \\
\text { Model } \\
\text { Score }\end{array}$ & $\begin{array}{l}\text { Tallgrass } \\
\text { Prairie } \\
\text { Model } \\
\text { Score }\end{array}$ & $\begin{array}{c}\text { Prairie } \\
\text { Wetland } \\
\text { Ecosyste } \\
\text { m Model } \\
\text { Score }\end{array}$ \\
\hline SW-5 & Welker & 21.96 & 0 & 28.8 & 17.87 & 14.13 & 49.01 \\
\hline $\mathrm{P}-22$ & Froland & 21.83 & 0 & 31.71 & 18.57 & 11.7 & 47.19 \\
\hline P-57 & Avok Slough & 21.81 & 0 & 33.82 & 21.3 & 8.43 & 45.52 \\
\hline $\begin{array}{l}\text { SW- } \\
12\end{array}$ & Quale & 21.65 & 18.63 & 32.36 & 27.45 & 7.98 & 21.83 \\
\hline B-47 & Johnson & 21.39 & 0 & 33.65 & 24.99 & 7.17 & 41.16 \\
\hline SV-36 & Pieske & 21.11 & 0 & 35.45 & 19.75 & 9.64 & 40.7 \\
\hline P-53 & Barsness & 21.1 & 0 & 37.3 & 37.43 & 5.44 & 25.33 \\
\hline SV-31 & Telkamp & 21.07 & 0 & 30.53 & 23.79 & 6.28 & 44.74 \\
\hline$L-3$ & Larson LQP & 21.06 & 0 & 35.69 & 28.48 & 10.5 & 30.65 \\
\hline $\begin{array}{l}\text { SW- } \\
11 \\
\end{array}$ & Westhausen & 20.91 & 0 & 26.46 & 22.78 & 9.1 & 46.19 \\
\hline T-6 & Jenk & 20.77 & 0 & 43.05 & 20.11 & 6.34 & 34.37 \\
\hline SV-40 & Mero & 20.62 & 0 & 36.93 & 31.35 & 8.32 & 26.48 \\
\hline SV-10 & Sherstad Slough & 20.55 & 0 & 30.98 & 20.59 & 10.58 & 40.61 \\
\hline B-31 & Moulton Lake & 20.5 & 0 & 34.59 & 24.44 & 7.1 & 36.37 \\
\hline $\mathrm{P}-00$ & Ashley & 20.5 & 0 & 42.27 & 28.96 & 8.2 & 23.05 \\
\hline B-39 & Jacobson & 20.36 & 0 & 31.96 & 19.79 & 6.81 & 43.23 \\
\hline P-56 & Cyrus & 20.33 & 0 & 33.8 & 10.32 & 3.51 & 54.03 \\
\hline SV-25 & Struck & 20.28 & 0 & 30.01 & 17.46 & 8.82 & 45.12 \\
\hline B-27 & Jorgenson & 20.26 & 0 & 26.71 & 15.7 & 9.2 & 49.71 \\
\hline SV-54 & Welfare & 20.12 & 0 & 34.24 & 16.17 & 5.97 & 44.24 \\
\hline B-22 & Wagner & 19.96 & 0 & 20.87 & 24.42 & 22.04 & 32.48 \\
\hline $\mathrm{L}-4$ & Colbert & 19.43 & 0 & 28.41 & 15.34 & 10.27 & 43.12 \\
\hline$L-15$ & Hackert & 19.29 & 0 & 32.78 & 20.55 & 9.24 & 33.9 \\
\hline SV-32 & Lee & 19.28 & 0 & 25.4 & 18.15 & 7.21 & 45.66 \\
\hline SV-27 & Bahr & 19.18 & 0 & 31.78 & 15.12 & 5.34 & 43.68 \\
\hline P-34 & Jorgenson & 19.03 & 0 & 34.16 & 12.72 & 6.36 & 41.92 \\
\hline $\mathrm{L}-11$ & Garfield & 18.85 & 0 & 23.39 & 16.94 & 6.85 & 47.05 \\
\hline B-37 & Powers & 18.79 & 0 & 26.72 & 17.91 & 3.58 & 45.73 \\
\hline B-10 & Toqua & 18.65 & 0 & 31.92 & 15.06 & 2.16 & 44.13 \\
\hline SV-46 & Nordby & 18.47 & 5.59 & 28.19 & 14.49 & 7.08 & 37.01 \\
\hline SV-51 & Big Stone & 18.47 & 0 & 20.16 & 13.76 & 9.25 & 49.16 \\
\hline SV-15 & Hutchinson & 18.43 & 0 & 25.86 & 13.53 & 8.54 & 44.24 \\
\hline P-33 & Stearns & 18.25 & 0 & 33.69 & 26.35 & 7.63 & 23.57 \\
\hline SV-14 & Mau & 18.2 & 0 & 26.59 & 18.45 & 7.68 & 38.28 \\
\hline SW-7 & Bowman & 17.92 & 0 & 26 & 25 & 4.54 & 34.08 \\
\hline
\end{tabular}




\begin{tabular}{|c|c|c|c|c|c|c|c|}
\hline $\begin{array}{c}\text { WPA } \\
\text { ID }\end{array}$ & WPA NAME & $\begin{array}{c}\text { Overall } \\
\text { Model } \\
\text { Score }\end{array}$ & $\begin{array}{c}\text { T and E } \\
\text { Model } \\
\text { Score }\end{array}$ & $\begin{array}{c}\text { Breeding } \\
\text { Waterfo } \\
\text { wl Model } \\
\text { Score }\end{array}$ & $\begin{array}{c}\text { Grassland } \\
\text { Birds } \\
\text { Model } \\
\text { Score }\end{array}$ & $\begin{array}{l}\text { Tallgrass } \\
\text { Prairie } \\
\text { Model } \\
\text { Score }\end{array}$ & $\begin{array}{c}\text { Prairie } \\
\text { Wetland } \\
\text { Ecosyste } \\
\text { m Model } \\
\text { Score }\end{array}$ \\
\hline B-58 & Lane & 17.91 & 0 & 36.04 & 13.27 & 4.18 & 36.07 \\
\hline $\mathrm{P}-7$ & Bailey & 17.86 & 0 & 28.89 & 21.41 & 5.25 & 33.73 \\
\hline SV-35 & Koehntop & 17.78 & 0 & 38.17 & 27.33 & 2.88 & 20.5 \\
\hline SV-39 & Allen & 17.68 & 0 & 27.6 & 20.49 & 5.68 & 34.65 \\
\hline B-59 & Centennial & 17.56 & 0 & 16.04 & 17.75 & 22.21 & 31.78 \\
\hline $\mathrm{P}-44$ & Gorder (west) & 17.23 & 0 & 32.83 & 27.46 & 2.4 & 23.48 \\
\hline SV-28 & Anderson & 17.14 & 0 & 25.27 & 24.27 & 2.49 & 33.65 \\
\hline $\begin{array}{l}\text { SW- } \\
27\end{array}$ & Maki & 17.1 & 0 & 17.32 & 14.76 & 7.22 & 46.19 \\
\hline SV-26 & Horton & 17.1 & 0 & 20.78 & 13.19 & 6.78 & 44.76 \\
\hline $\mathrm{P}-4$ & Lake Emily & 17.06 & 0 & 26.08 & 20.02 & 3.66 & 35.53 \\
\hline SV-42 & Landers & 16.98 & 0 & 19.16 & 18.74 & 2.53 & 44.47 \\
\hline B-18 & Bauman & 16.85 & 0 & 27.47 & 8.73 & 3.56 & 44.5 \\
\hline SV-33 & Miller & 16.82 & 0 & 28.28 & 12.69 & 8.16 & 34.96 \\
\hline B-7 & Humpty Dumpty & 16.78 & 0 & 34.62 & 25.01 & 2.62 & 21.66 \\
\hline SV-11 & Golden & 16.77 & 0 & 28.97 & 29.86 & 8.67 & 16.37 \\
\hline SV-44 & Sprouls & 16.54 & 0 & 28.21 & 12.52 & 1.42 & 40.54 \\
\hline SW-2 & Hoffman & 16.45 & 0 & 20.33 & 14.9 & 3.53 & 43.49 \\
\hline B-42 & Wiley & 16.36 & 0 & 20.95 & 12.88 & 9.12 & 38.86 \\
\hline $\mathrm{P}-30$ & Hoff & 16.18 & 0 & 23.25 & 18.23 & 4.09 & 35.32 \\
\hline YM-2 & Busack & 15.91 & 0 & 20.37 & 21.92 & 1.98 & 35.27 \\
\hline B-41 & Bentson Lake & 15.85 & 0 & 36.62 & 23.06 & 4.69 & 14.87 \\
\hline B-54 & Dybdahl & 15.82 & 0 & 25.03 & 21.14 & 6.14 & 26.8 \\
\hline $\mathrm{L}-2$ & Bailey Slough & 15.78 & 0 & 18.45 & 14.39 & 11.77 & 34.31 \\
\hline $\mathrm{P}-31$ & Moe & 15.77 & 0 & 25.27 & 6.2 & 4.57 & 42.81 \\
\hline SV-4 & Solvie & 15.72 & 0 & 19.71 & 17.56 & 4.84 & 36.51 \\
\hline B-17 & O'connell & 15.69 & 0 & 35.49 & 15.76 & 2.63 & 24.59 \\
\hline $\begin{array}{l}\text { SW- } \\
20\end{array}$ & Byre & 15.23 & 0 & 14.1 & 11.05 & 5.35 & 45.63 \\
\hline SW-3 & Hamann & 15.23 & 0 & 15.6 & 17.57 & 7.06 & 35.93 \\
\hline B-7A & Graceville & 15.13 & 0 & 30.27 & 22.24 & 0 & 23.13 \\
\hline B-55 & Akron & 14.97 & 0 & 21.78 & 11.27 & 6.08 & 35.71 \\
\hline SV-48 & Weiler & 14.81 & 0 & 22.66 & 16.99 & 4.91 & 29.49 \\
\hline $\mathrm{P}-23$ & Starbuck & 14.65 & 0 & 33.19 & 20.17 & 8.42 & 11.47 \\
\hline B-11 & Piper & 14.57 & 0 & 31.19 & 27.72 & 2.73 & 11.2 \\
\hline P-37 & Mattson & 14.5 & 0 & 30.69 & 14.03 & 2.6 & 25.17 \\
\hline P-25 & Rustad & 14.49 & 0 & 17.41 & 11.89 & 6.38 & 36.77 \\
\hline
\end{tabular}




\begin{tabular}{|c|c|c|c|c|c|c|c|}
\hline $\begin{array}{l}\text { WPA } \\
\text { ID }\end{array}$ & WPA NAME & $\begin{array}{c}\text { Overall } \\
\text { Model } \\
\text { Score }\end{array}$ & $\begin{array}{c}\text { T and E } \\
\text { Model } \\
\text { Score }\end{array}$ & $\begin{array}{c}\text { Breeding } \\
\text { Waterfo } \\
\text { wl Model } \\
\text { Score } \\
\end{array}$ & $\begin{array}{c}\text { Grassland } \\
\text { Birds } \\
\text { Model } \\
\text { Score } \\
\end{array}$ & $\begin{array}{c}\text { Tallgrass } \\
\text { Prairie } \\
\text { Model } \\
\text { Score } \\
\end{array}$ & $\begin{array}{c}\text { Prairie } \\
\text { Wetland } \\
\text { Ecosyste } \\
\text { m Model } \\
\text { Score }\end{array}$ \\
\hline B-28 & Haugen & 14.36 & 0 & 28.14 & 18 & 1.84 & 23.82 \\
\hline $\mathrm{P}-1$ & Osterberg Lake & 14.31 & 0 & 21.58 & 12.56 & 3.53 & 33.86 \\
\hline B-25 & Lindholm & 14.27 & 0 & 19.4 & 21.78 & 3.42 & 26.77 \\
\hline B-46 & Goldsmith & 14.24 & 0 & 24.02 & 21.04 & 2.2 & 23.96 \\
\hline $\mathrm{P}-45$ & Gorder (east) & 14.11 & 0 & 34.14 & 24.98 & 1.99 & 9.42 \\
\hline$P-60$ & Snetting & 14.06 & 0 & 21.97 & 12.82 & 6.95 & 28.56 \\
\hline SV-9 & Moore & 14.04 & 0 & 19.03 & 16.92 & 8.09 & 26.18 \\
\hline$P-9$ & Ann Lake & 14.03 & 0 & 32.41 & 6.12 & 7.3 & 24.33 \\
\hline SV-1 & Stimmler & 13.95 & 0 & 19.75 & 8.98 & 4.84 & 36.17 \\
\hline B-49 & Arndt & 13.88 & 0 & 25.08 & 20.55 & 0.49 & 23.27 \\
\hline B-38 & Persen & 13.83 & 0 & 15.8 & 14.26 & 4.68 & 34.41 \\
\hline B-44 & Almond & 13.73 & 0 & 19.87 & 21.79 & 2.41 & 24.56 \\
\hline SV-43 & Alberta & 13.58 & 0 & 25.82 & 6.06 & 2.4 & 33.62 \\
\hline SV-37 & Fitzgerald & 13.5 & 0 & 10.54 & 7.42 & 3.86 & 45.69 \\
\hline P-49 & $\begin{array}{l}\text { Gullickson } \\
\text { (south) }\end{array}$ & 13.39 & 0 & 31.32 & 21.59 & 3.28 & 10.75 \\
\hline SW-6 & Rice & 13.02 & 0 & 19.13 & 14.89 & 6.44 & 24.64 \\
\hline B-5 & Holmblad & 12.83 & 0 & 20.97 & 19.31 & 0.41 & 23.44 \\
\hline$P-65$ & State Lake & 12.71 & 0 & 25.32 & 13.63 & 10.01 & 14.57 \\
\hline SV-50 & Huebner & 12.7 & 0 & 21.51 & 16.7 & 3.71 & 21.6 \\
\hline$B-36$ & Foster & 12.58 & 0 & 17.18 & 20.01 & 2.02 & 23.69 \\
\hline B-48 & Malta & 12.52 & 0 & 15.48 & 11.57 & 8.83 & 26.71 \\
\hline SV-34 & $\begin{array}{l}\text { Pomme de Terre } \\
\text { Lake }\end{array}$ & 12.45 & 0 & 18.47 & 9.06 & 8.59 & 26.14 \\
\hline T-7 & Gibson & 11.85 & 0 & 22.97 & 3.46 & 7.71 & 25.13 \\
\hline $\begin{array}{l}\text { SW- } \\
22\end{array}$ & Benson & 10.86 & 0 & 16.79 & 16.22 & 8.92 & 12.35 \\
\hline T-5 & Hormann & 10.46 & 0 & 11.93 & 7 & 5.1 & 28.25 \\
\hline SV-12 & Staples & 10.41 & 0 & 14.28 & 15.18 & 2.79 & 19.82 \\
\hline B-35 & $\begin{array}{l}\text { Middlewest } \\
\text { Investment }\end{array}$ & 10.27 & 4.34 & 9.53 & 11.78 & 1.56 & 24.13 \\
\hline $\mathrm{L}-14$ & Quaal & 9.79 & 0 & 12.56 & 5.97 & 5.82 & 24.58 \\
\hline P-48 & $\begin{array}{l}\text { Gullickson } \\
\text { (north) }\end{array}$ & 9.74 & 0 & 26.15 & 20.79 & 1.57 & 0.2 \\
\hline B-19 & Curran & 9.74 & 0 & 24.75 & 0.2 & 0.21 & 23.53 \\
\hline B-43 & Hanson Estate & 9.35 & 0 & 9.02 & 11.15 & 2.72 & 23.88 \\
\hline SV-30 & Cheney Trust & 8.59 & 0 & 10.43 & 4.78 & 2.87 & 24.86 \\
\hline SV-24 & Grote & 8.05 & 0 & 8.8 & 3.01 & 3.74 & 24.68 \\
\hline
\end{tabular}




\begin{tabular}{|c|c|c|c|c|c|c|c|}
\hline $\begin{array}{c}\text { WPA } \\
\text { ID }\end{array}$ & WPA NAME & $\begin{array}{c}\text { Overall } \\
\text { Model } \\
\text { Score }\end{array}$ & $\begin{array}{c}\text { T and E } \\
\text { Model } \\
\text { Score }\end{array}$ & $\begin{array}{c}\text { Breeding } \\
\text { Waterfo } \\
\text { wl Model } \\
\text { Score }\end{array}$ & $\begin{array}{c}\text { Grassland } \\
\text { Birds } \\
\text { Model } \\
\text { Score }\end{array}$ & $\begin{array}{l}\text { Tallgrass } \\
\text { Prairie } \\
\text { Model } \\
\text { Score }\end{array}$ & $\begin{array}{l}\text { Prairie } \\
\text { Wetland } \\
\text { Ecosyste } \\
\text { m Model } \\
\text { Score }\end{array}$ \\
\hline B-10A & Swenson & 7.64 & 0 & 13.51 & 0.56 & 0.92 & 23.23 \\
\hline$L-9$ & Sumner & 7.47 & 0 & 12.58 & 11.19 & 2.45 & 11.13 \\
\hline SV-6 & Hancock & 7.27 & 0 & 0 & 0 & 2.09 & 34.25 \\
\hline$P-47$ & Aal & 6.68 & 0 & 16.26 & 4.3 & 2.63 & 10.22 \\
\hline P-24 & Jackson & 6.67 & 0 & 16.12 & 13.48 & 2.5 & 1.24 \\
\hline B-40 & Clinton & 6.63 & 0 & 2.51 & 5.52 & 0.98 & 24.12 \\
\hline SV-49 & Chokio & 6.28 & 0 & 2.39 & 3.99 & 1.24 & 23.77 \\
\hline SW-9 & Stock & 6.28 & 0 & 2.69 & 2.03 & 2.54 & 24.15 \\
\hline SV-47 & Darnen & 5.42 & 2.63 & 13.02 & 4.58 & 5 & 1.85 \\
\hline B-34 & Cornish & 4.04 & 0 & 11.1 & 6.78 & 1.35 & 0.97 \\
\hline SV-41 & Stahn & 3.87 & 0 & 9.51 & 7.66 & 2.16 & 0 \\
\hline
\end{tabular}

